University of Rhode Island

DigitalCommons@URI

Open Access Dissertations

2014

\title{
Moral Elevation and its Relation to the Altruistic Health Behavior of Becoming an Organ and Tissue Donor
}

Nicole Amoyal

University of Rhode Island, nnamoyal@gmail.com

Follow this and additional works at: https://digitalcommons.uri.edu/oa_diss

\section{Recommended Citation}

Amoyal, Nicole, "Moral Elevation and its Relation to the Altruistic Health Behavior of Becoming an Organ and Tissue Donor" (2014). Open Access Dissertations. Paper 197.

https://digitalcommons.uri.edu/oa_diss/197

This Dissertation is brought to you for free and open access by DigitalCommons@URI. It has been accepted for inclusion in Open Access Dissertations by an authorized administrator of DigitalCommons@URI. For more information, please contact digitalcommons-group@uri.edu. 
MORAL ELEVATION AND ITS RELATION TO THE ALTRUISTIC HEALTH BEHAVIOR OF BECOMING AN ORGAN AND TISSUE DONOR BY NICOLE REBECCA AMOYAL

A DISSERTATION SUBMITTED IN PARTIAL FULFILLMENT OF THE REQUIREMENTS FOR THE DEGREE OF DOCTOR OF PHILOSOPHY

IN

CLINICAL PSYCHOLOGY

UNIVERSITY OF RHODE ISLAND 


\section{DOCTOR OF PHILOSOPHY IN CLINICAL PSYCHOLOGY \\ OF}

NICOLE AMOYAL

APPROVED:

Dissertation Committee:

Major Professor: Mark Robbins

Andrea Paiva

Sue Adams

Nasser H. Zawia

DEAN OF THE GRADUATE SCHOOL

UNIVERSITY OF RHODE ISLAND

2014 


\begin{abstract}
Recent research in the field of positive psychology has concentrated efforts towards understanding positive prosocial emotional experiences in relation to prosocial behavior. Elevation is one of these emotions that has been described as a powerful and positive mood state that can be experienced by witnessing social moral acts (Haidt, 2000) and has recently been linked to increases in prosocial behavior (Freeman, Aquino, \&McFerren, 2009; Landis, Sherman, Piedmont, Kirkhart, Rapp, \& Bike, 2009; Schnall, Roper, \&Fessler, 2010). This study investigated the emotion elevation in relation to decision-making for the prosocial health behavior of becoming an organ and tissue donor. The study was experimental and compared decision making for becoming an organ and tissue donor across experimental and control groups. Participants were randomized to one of the three conditions (elevation, mirth, and neutral state) to see if elevation versus control conditions influenced attitudes and behaviors in regards to organ and tissue donation decision-making, and stress management before and after watching a brief video clip. The methodology was also novel in that an online video induction of elevation has not been previously investigated. It was hypothesized that elevation would lead to increased readiness to become an organ and tissue donor, as well as endorsement of greater Pros, SelfEfficacy, engagement, and stress management. Results indicated that participants in the elevation condition reported significantly higher ratings of state elevation compared to positive and neutral control groups supporting that elevation can be induced with an online video protocol. Post-test results indicated that state elevation was not predictive of group differences on decisional balance, self-efficacy, stage,
\end{abstract}


engagement, actual registration for organ and tissue donation, and stress management. As predicted, women reported significantly greater trait elevation than men and trait elevation was significantly related to stage for organ and tissue donation. Questions remain as to the utility of moral elevation state to impact prosocial behaviors.

Limitations are discussed and suggestions for future research include utilizing online video induction of moral elevation to better understand the behavioral antecedents of this emotion in naturalistic settings. 


\section{ACKNOWLEDGMENTS}

With the sincerest gratitude, I would like to thank my major professor, Mark Robbins, Ph.D., and committee members, Andrea Paiva, Ph.D., Sue Adams, Ph.D, and Nasser H. Zawia, Ph.D. for their guidance, advice, and helpful comments throughout the course of this study. Specifically, I would like to express gratitude towards Dr. Robbins for facilitating an environment where creativity could flourish. In addition, Dr. Robbins has provided expert guidance in the value of clearly framing the bigpicture and purpose of research, necessary for grant writing, and has helped me enhance my professional skills as a researcher. His unconditional positive support has been instrumental towards my professional development. I would also like to thank Dr. Andrea Paiva for her mentorship, which has been central throughout graduate school and in all aspects of this project. In addition, her leadership, direction, and friendship have been crucial to my productivity and professional development.

In addition, I would also like to thank all of the inspiring mentors I have had the privilege to work with over the course of my undergraduate and graduate educational experiences. Specifically, Dr.'s Robert Deluty, James Fauerbach, Neda Gould, Shawn Mason, Nida Corry, and James Lynch have shaped my professional trajectory and it is with sincerest gratitude that I express my appreciation for their guidance.

Finally, I would like to thank my parents Sherryl Gussio Amoyal and Abraham Avi Amoyal for their unconditional love, moral, and financial support. They have instilled in me the value of education and have made sacrifices for me to pursue my 
dreams. For that, I will forever be grateful. Finally, I would like to thank my brothers Tony and Joseph for their love, humor, and support. My family is my life compass. 
TABLE OF CONTENTS

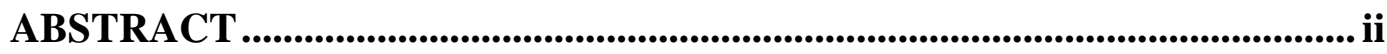

ACKNOWLEDGEMENTS............................................................................ iv

TABLE OF CONTENTS.............................................................................. vi

LIST OF TABLES ............................................................................................. vii

LIST OF FIGURES ..................................................................................... viii

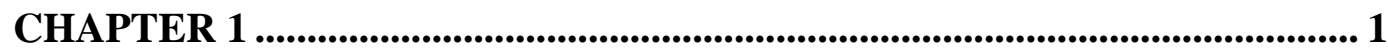

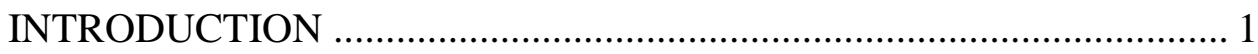

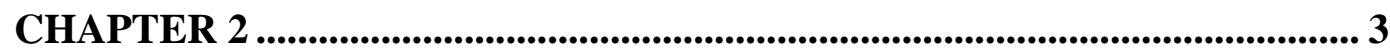

REVIEW OF THE LITERATURE.................................................... 3

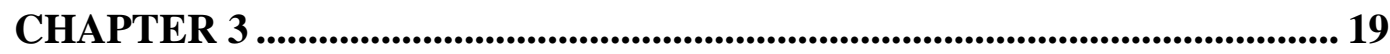

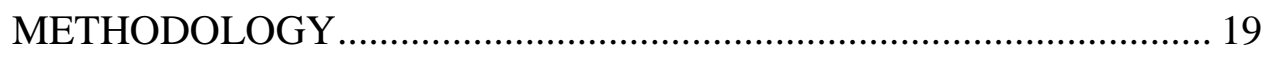

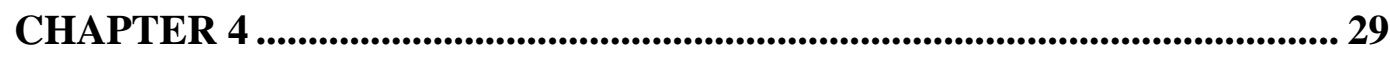

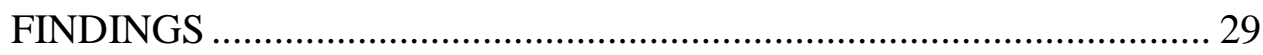

CHAPTER 5 ................................................................................................................... 47

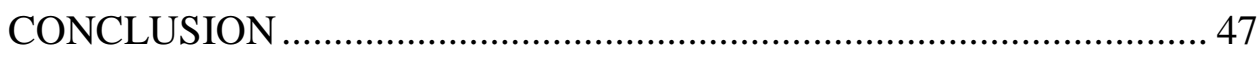

APPENDICES .............................................................................................................. 56

REFERENCES..................................................................................................... 80 


\section{LIST OF TABLES}

\section{TABLE}

Table 1.General Demographic Characteristics of the Participants ...................... 31

Table 2. Correlation Matrix of Main Study Constructs .................................... 32

Table 3. Participants per Condition............................................................ 33

Table 4.Means for Self-Ratings of Elevation State Items ............................... 37

Table 5.Means for Self-Ratings of Elevation State Items by Gender .................. 36

Table 6. Baseline Stage Distribution by Gender ...................................... 38

Table 7. Decisional Balance items by Elevation State Items per Condition ........ 40

Table 8. Pre-test Stage and Post-test Intentions by Condition ............................ 45

Table 9. Actual Participant Registration by Group................................. 45 


\section{LIST OF FIGURES}

FIGURE

FIGURE 1. Flow Chart of Recruitment and Retention........................................... 30 


\section{CHAPTER 1}

\section{INTRODUCTION}

There is a need to increase the efficacy of health behavior change interventions because some public health problems such as blood and organ donation can only be solved by prosocial actions (Milaniak, Przybylowski, Wierzbicki, \&Sadowski, 2010). Today, there are over 111,800 men, women, and children on the transplant waiting list (National Kidney Foundation factsheet, www.kidney.org (2011). In order to solve the shortage of available organs, interventions to increase organ and tissue donor registration must be developed with the potential to be disseminated through technological platforms that can reach large populations. In addition, the interventions must be powerful enough to promote behavior change (e.g., documented organ and tissue donor registration).

Traditionally interventions and public campaigns have emphasized guilt and dramatic relief (i.e., donating money to resolve feelings of guilt) as means to engage individuals' attention to issues and involvement in prosocial behaviors. However, research in positive psychology has suggested that producing positive affective states may be even more effective to increase attention and promote immediate and lasting behavior change (Fredrickson, 2001). Elevation is a positive mood state that has been consistently shown to increase prosocial behavior in laboratory-based studies (Thomson \& Siegel, 2012; Aquino, McFerran, \&Laven, 2011; Freeman, Aquino, \&McFerran, 2009; Schnall, Roper, \&Fessler, 2010; Schnall\& Roper, 2011). The current study expanded upon the research by evaluating the impact of moral elevation on decisions regarding becoming an organ and tissue donor in a non-laboratory setting 
via a more practical, computer-based delivery. Moral state elevation was compared to mirth and neutral affect conditions to evaluate interest and decision making in becoming an organ and tissue donor. Decision making regarding organ and tissue donation was assessed based on the Transtheoretical Model's constructs of behavior change that have been previously established in over 50 health behaviors. 


\section{CHAPTER 2}

\section{Organ Donation}

As of March, 2013, there were over 111,800 men, women, and children awaiting an organ transplant in America. On average, thirteen of these individuals die every day waiting for an organ (National Kidney Foundation factsheet, www.kidney.org (2011)). Due to the shortage of available organs, there is a great need for organ and tissue donors. The process for becoming an organ and tissue donor is typically defined as making a decision, documenting it (e.g., donor card, online registry) and informing family or loved ones of intentions to donate. There are many factors that influence the process of becoming an organ and tissue donor. Amongst the contributing factors include that organ and tissue donation are specific prosocial health behaviors that require altruistic motivation to solve because they require sacrifices that may yield no direct benefit to the donor (Milaniak, Przybylowski, Wierzbicki, \&Sadowski, 2010). In addition, organ and tissue donation are population-based problems because they require a large population of individuals to declare intent to donate in order to maximize availability of deceased organs since becoming a solid organ donor is a low base rate event. Further, interventions to increase these prosocial behaviors require theoretical frameworks and corresponding methods with the capability of helping entire populations make behavior changes. Research to date on the prosocial emotion, elevation, suggests that this mood state is a good candidate to investigate how it affects organ donation intentions both by increasing positive feelings towards donation intent and by increasing engagement (interest and attention) in interventions that can be delivered on a population basis. In sum, intervention 
development should focus on methods that 1) are based on a solid, empirical, behavior change framework; 2) increase prosocial motivation; and 3) have the potential to be delivered on a population basis in order to have maximum impact.

\section{The Transtheoretical Model}

All interventions to increase health behaviors (including altruistic ones) should utilize a theoretical framework in order to provide an evidence-based approach for evaluation and standardization of dissemination. The Transtheoretical Model (TTM) is especially relevant to organ donation because it is a health behavior change model that provides a good foundation for health behavior change interventions. When combined with modern computer-based assessment and intervention technologies this model is well-suited for use with entire populations, not just those most ready for behavior change. The TTM can be utilized to measure and influence readiness to make behavior change or adopt a particular health behavior, and has been applied to over 50 health behaviors. The Transtheoretical Model (TTM) explains motivation and intentional behavior change based on thoughts, experiences, and behaviors and describes the relationship between four key constructs including Stages of Change, Decisional Balance, Self Efficacy, and Processes of Change (Prochaska and DiClemente, 1983; DiClemente et al., 1991). The TTM has already been applied to blood and organ donation decision-making (Waterman, Robbins, Paiva, \& Hyland, 2010; Robbins, 1998; Robbins, Levesque, Redding, \& Johnson, 2001; Burditt, Paiva, Robbins, Velicer, Koblin, \& Kessler, 2009). Interventions based on the TTM are tailored on the central organizing construct of Stage of Change as well as constructs 
including Decisional Balance (Pros and Cons), Self-Efficacy, and Processes of Change (POC).

Stage of Change

Stage of Change or "readiness" for change is the central organizing construct of the TTM and refers to a series of categorical steps while changing behavior. The stages of change are typically defined as Precontemplation (not thinking about change in the next 6 months), Contemplation (planning to change in the next 6 months), Preparation (planning to change in the next 30 days), Action (changed within the last 30 days), and Maintenance (sustained change for past 6 months) (Prochaska and DiClemente, 1983; DiClemente et al., 1991). Stage of change has specifically been applied to organ donation and is broadly defined as Precontemplation (I am not considering becoming an organ donor), Contemplation (I am considering the option of organ donation within the next six months, but have not yet made that decision), Preparation (I am considering becoming an organ donor within the next 30 days or at next available opportunity or I have decided to become an organ and tissue donor but have not told my family and/or have not gotten documentation), and Action/Maintenance (I have decided to become an organ and tissue donor, told my family of my wishes, and have documentation; e.g., have met all three criteria). In a study investigating organ donation in a predominantly White college student sample, the stage distribution for was $17 \%$ in Precontemplation (PC), 24\% in Contemplation (C), 17\% in Preparation (P), and $42 \%$ in Action and Maintenance (A/M) (Hall, Robbins, Paiva, Knott, Harris, \&Mattice, 2007). A second study evaluated the Stage of Change, and the distribution in this population sample was $28 \%$ in $\mathrm{PC}, 18 \%$ in $\mathrm{C}$, 
$20 \%$ in $\mathrm{P}$ and $33 \%$ in A/M. Given the discrepant statistics in a sample of college students and the general population with greater number of students in Action/ Maintenance and lesser number in Precontemplation, accordingly, interventions must appeal to various levels of willingness to donate (Hall et al., 2007).

\section{Decisional Balance}

Decisional Balance is a TTM construct that reflects the decision process of evaluating the benefits (Pros) and the negative consequences (Cons) of behavior change. A consistent pattern of the Pros and Cons by stage has been repeatedly found across numerous studies and content areas such that the Pros increase by one standard deviation when individuals move from Precontemplation to Action (Prochaska et al., 1994; Hall\&Rossi, 2008)and the Cons decrease by a half of a standard deviation (Hall \& Rossi, 2008). This suggests that although Cons remain associated with behavior change, the Pros are more influential. In a recent study investigating kidney patients' intention to receive a deceased donor transplant, Pros and Cons were significantly related to Stage of Change such that endorsement of Pros were the lowest in Precontemplation and endorsement of Cons were the lowest in Maintenance (Waterman, Robbins, Paiva, \& Hyland, 2010). Furthermore, summarizing what has been influential in increasing willingness to become an organ and tissue donor include interventions that focus on the Pros of organ donation and dispelling medical myths (Siegel et al., 2008).

\section{Self-Efficacy}

Self-Efficacy is defined as situational confidence associated with making a particular behavior change (Bandura, 1977; DiClemente, Prochaska, Gibertini, 1985). 
While Self-efficacy is influential across all Stages of Change, it has been demonstrated to be most influential in the later Stages of Change. In sum, Self-efficacy is expected to increase as progression through the Stages of Change increases (Rossi \& Redding, 2001). In a recent study investigating kidney patients' intention to receive a deceased donor transplant, Self-efficacy was positively correlated with Stage of Change such that participants in Action/ Maintenance reported significantly greater Self-efficacy compared to participants in Precontemplation (Waterman et al., 2010).

\section{Processes of Change}

The Processes of Change (POC) represent overt and covert activities in which individuals engage as they change a behavior. These change processes represent independent variables that can be targeted to help increase the value of the pros, decrease the value of the cons and increase self-efficacy to help individuals progress through the stages of change (DiClemente \& Prochaska, 1982; Prochaska \& DiClemente, 1983; Prochaska \& Norcross, 1983; Prochaska \& DiClimente, 1985; Prochaska et al., 1988). The POC are composed of two higher order constructs, experiential and behavioral POC. Experiential POC are thoughts and feelings used to engage in behavior change and include Consciousness Raising (increased awareness about the behavior), Dramatic Relief (increased emotional experiences so to reduce the affect to increase behavior), Environmental Reevaluation (how behavior effect's one's social environment), Self Reevaluation (viewing self-image with and without behavior change), and Social Liberation (increase in social opportunities/ alternatives with behavior change). Behavioral processes consist of activities such as making commitments and acting to promote change. The behavioral POC include Self 
Liberation (increase commitment to change and recommitment to act on that change), Reinforcement Management (provides consequences for taking steps towards a healthy behavior), Helping Relationships (increasing caring, trust, openness, acceptance, and social support for behavior change), Counter Conditioning (learning healthier behaviors that can substitute for problem behaviors), and Stimulus Control (removing cues for unhealthy habits and adding prompts for healthier alternatives). Each is theoretically unique with respect to their mechanism of action within behavior change, although empirically the POC are highly intercorrelated. The TTM postulates that the value of the processes of change varies by stage of change with experiential processes being more important for progress in early stages and behavioral processes more important in later stages (DiClemente\&Prochaska, 1982;

Prochaska\&DiClemente, 1983; Prochaska\& Norcross, 1983; Prochaska\&DiClimente, 1985; Prochaska et al., 1988).

Dramatic Relief is one of the TTM POC and is, on face value, most directly related to negative affective experience associated with the desired health behavior. Dramatic Relief is described as "experiencing and expressing feelings about one's problems and solutions" (Prochaska, DiClemente, \& Norcross, 1992, pp. 671) and typically utilizes negative emotional experience to motivate behavior change (e.g., "I am moved by stories of people whose lives are saved by organ donation").Negative emotional states are frequently used to spur pro-social behavior such as becoming an organ tissue donor or donating to charity. However, the use of negative states in this way has limitations. People tend to respond to negative emotions by acting in ways only to reduce negative affective experience in the context at hand (i.e. reduce guilt by 
giving money). The TTM Processes of Change may fall short of incorporating the breadth of emotions that have been understood to influence decision-making due to insufficient focus on positive emotional experience related to behavior change. Recent research suggests that positive emotions have broader effects on behavior (Fredrickson, 2001) and may impact health behavior change.

\section{Elevation}

An approach toward increasing engagement and prosocial behavior that has been recently suggested is focusing on positive emotional states. In particular, research on a relatively newly investigated positive emotional state, elevation, has suggested that this affective state may be particularly effective at increasing participation in prosocial behaviors. State elevation is a positive emotion that can be experienced upon witnessing, hearing, or reading about an altruistic act of kindness (Haidt, 2000). It has been described as a powerful social moral emotion associated with physical sensations including warm, open feelings ('dilation') in the chest (potentially due to increases in oxytocin (Silvers \&Haidt, 2008); and it motivates people to behave more virtuously themselves (Haidt, 2000). Recently, it has been related to the release of oxytocin in nursing mothers' (Silvers \&Haidt, 2008). In addition, women have reported greater endorsement of elevation than men (Landis et al., 2009). Most importantly, elevation has been empirically demonstrated to be related increases in altruistic behavior (Aquino, McFerren, \&Laven, 2011; Freeman, Aquino, \&McFerran, 2009; Schnall, Roper, \&Fessler, 2010; Schnall\& Roper, 2011).

In a series of laboratory-based studies, elevation had a significant effect on increasing altruistic behavior (Aquino et al., 2011; Freeman et al., 2009; Schnall et al., 
2010; Haidt, 2000; Schnall\& Roper, 2011). Three studies were conducted to demonstrate the relationship between elevation, Social Dominance Orientation, and donation behavior (Freeman et al., 2009). Social Dominance Orientation refers to the comparison between the majority group and minority groups in a society and the advantages associated with the former and the disadvantages associated with the latter (Freeman et al., 2009). The experience of elevation (induced by having participants watch video about a man who performed a virtuous act) was used to dissipate the negative biases associated with social prejudice (Freeman et al., 2009). Results showed that Social Dominance Orientation was related to White participants' donations to a Black-oriented charity (i.e., United Negro College Fund) such that greater the social dominance orientation, the lesser the donation. The second study induced elevation via video in a laboratory-based setting and found the White participants in the moral elevation condition increased donations to a minority organization (thus reducing the negative effects of Social Dominance Orientation). The third study found that the experience of moral elevation was related to increased donations to a White-oriented charity. In addition, moral elevation was related to reduced Social Dominance Orientation (Freeman et al., 2009). These studies suggest that not only does elevation influence donation activity, but elevation also worked to offset negative attitudes such as Social Dominance Orientation (Freeman et al., 2009).

In a similar study, inducing elevation via the same film clip (about a man performing a virtuous act) was found to increase participants' short-term engagement in two types of helping behavior (i.e., volunteering for a subsequent unpaid study and spending time helping the experimenter with a tedious task) in the elevation condition 
(Schnall et al., 2010). Recent studies have shown that elevation does not need to be context specific (e.g., video content not related to desired helping behavior) to increase prosocial behavior. However, in one study investigating volunteer behavior, elevation was related to an increase in volunteer behavior but only within the context the emotion was experienced. In other words, participants' report of elevation experienced during a volunteer trip predicted repeated participation in the same volunteer experience one and three months later, but did not predict general volunteerism (Cox, 2010). In sum, experiences of elevation were related to increased prosocial behavior.

The mood state of elevation is positive and powerful, and over time, the habitual experience of elevation can also impact behavior. Trait elevation is defined as the habitual experience of elevation over time and is positively related to Big Five Personality Traits such as Openness to Experience, Extraversion, and Agreeableness (Landis, Sherman, Piedmont, Kirkhart, Rapp, \& Bike, 2009). In addition, trait elevation is also positively correlated with measures of spiritual transcendence and pro-social behavior (Landis et al., 2009). Research has supported that trait elevation has significant incremental validity above and beyond what personality characteristics can account for in participation in prosocial behavior. In other words, trait elevation can uniquely account for some variability related to participation in prosocial acts (Landis et al., 2009). In this study, in addition to the experimental component of assessing mood states on organ and tissue donation decision-making, trait elevation was assessed in relation to organ and tissue donation registration to better understand if the habitual experience of elevation was related to prosocial health behavior decision making for organ and tissue donation. 
Elevation has implications for motivating behavior via cognitive assimilation (expanding and integrating thought processes) as explained by Fredrickson's (2001) Broaden and Build theory of positive emotions. Though research on elevation is nascent, results to date provide support for the relationship between elevation and altruistic behavior and support further investigating how elevation relates to prosocial behavior. The elevation response is described as a prosocial action tendency where "the emotion puts the person into a motivational and cognitive state in which there is an increased tendency to engage in certain goal related actions" (Haidt, 2003, p. 854). Eliciting elevation could be a novel way to encourage organ donation intentions, especially when society is saturated with efforts to increase prosocial behavior (e.g. advertisements and public appeals that usually try to invoke more negative emotions (i.e. pity, guilt, or fear)) (Freeman et al., 2008). In sum, interventions that include a positive prosocial emotion could be a more effective way of encouraging prosocial behavior.

\section{Positive Emotions}

Fredrickson's (2001) Broaden and Build Theory suggest that positive emotions serve to broaden mindsets while negative emotions tend to narrow these same cognitive processes. Positive emotions have an immediate effect on expanding one's outlook, and over time, positive emotions can take on a more permanent, healthpromoting role by fostering a greater breadth of resources to draw from in times of need (Fredrickson, 2001). In sum,

"Positive emotions broaden thought and action repertoires, increase mental flexibility, augment meaning-based coping, and motivate engagement in novel 
activities and social relationships. Importantly, positive emotions, although transient, have lasting consequences; they build durable personal resources whose accrual triggers further positive emotions, leading to self-sustaining upward spirals of well-being" (Garland et al., 2010, pp. 860).

Kavanaugh and Bower (1985) investigated positive emotions in relationship to SelfEfficacy and suggest that the experience of positive emotion becomes associated with a specific activity increasing Self-Efficacy in completing the behavior. Furthermore, positive mood enhances self-efficacy in learning new skills because it facilitates motivation and persistence with the activity (Kavanaugh\& Bower, 1985). Besides an overall global effect of positive emotions, specific positive emotions may have specific contextual effects on various behaviors (i.e. elevation increases prosocial behavior). However, research has only begun to examine the contextual effects of specific positive emotions. The concept of differential broadening is a term used to describe the unique cognitive and behavioral implications of discrete positive emotions (Cavanaugh, 2009) investigated. Cavanaugh (2009) was the first to empirically demonstrate the effects of discrete positive emotions in consumer behavior (unpublished dissertation). Specifically, love and gratitude were more likely to lead to behaviors that yield benefits to others as opposed to hope, which yields more problemsolving behavior. Early results suggest, "emotions characterized as high in breadth of social connection (e.g., love) increase behaviors benefitting distant others" (p.82). Similarly, elevation is an emotion characterized as high social connection and could have similar effects on encouraging "behaviors benefitting distant others" (p.82) (i.e. organ donation). 


\section{Prosocial Behavior Well-being and Stress Management}

The mental and physical benefits of helping others are supported by outcomes inresearchinevolutionary psychology, physiology, and positive psychology (Post, 2005). "A strong correlation exists between the well-being, happiness, health, and longevity of people who are emotionally and behaviorally compassionate, so long as they are not overwhelmed by helping tasks (Post, 2005, p.66)." Over 18 studies highlighted the health benefits associated with prosocial behavior (Post, 2005). Healthy outcomes were inclusive of, but not limited to, decrease in depression rates in adolescents, increases in sense of purpose and lower symptoms of depression, reduced risk of dying, greater life satisfaction, and positive physiological effects such as reduction in stress hormones, and increases in a protective antibody.

Besides prosocial behavior, prosocial emotions can have important health benefits. People who are resilient are more likely to use positive emotions to recover from negative emotional experiences (Tugade\& Fredrickson, 2004). Additionally, positive emotions are used to find meaning in negative events which act as a buffer against stress (Tugade et al., 2004). In this vein, positive emotions are positively related to well-being and stress management so it is reasonable to suggest that a positive prosocial emotion such as elevation is also positively related to well-being and stress management. In theory, elevation has health related qualities associated with valence effects of positive emotions but may also have specific health related qualities associated with altruistic behaviors. Since organ donation is a prosocial behavior, it was hypothesized that participants' that were more ready to become an 
organ donor (i.e. further along in the stages) would endorse greater well-being and stress management compared to those in earlier stages.

\section{Engagement in Interventions}

Interventions to increase organ and tissue donation need to reach large populations to meet the public health need and computer-based (internet) interventions are a technological platform that can help achieve that goal. In addition, the TTM has been combined with individually tailored, computer application interventions to increase behavior change. The interventions are individually tailored based on TTM constructs (Stage of Change, Decisional Balance, and Self-efficacy). The individually tailored TTM components of the interventions are designed to increase engagement and interest in the content being delivered.

Strategies to increase engagement often include emotional appeal to increase participants' interest in a subject matter. Charitable and prosocial behavior campaigns frequently use sad stories and images to induce empathy, pity, or guilt to emotionally engage viewers and promote prosocial behavior. While this approach is often successful, campaigns that emphasize these emotions can produce "compassion fatigue," a phenomenon that results from overexposure to negative stimuli commonly portrayed in charitable advertisements (Freeman et al., 2008, Dvorkin, 2006). Compassion fatigue results in avoiding an issue or denying a problem exists due to overexposure to emotional stories of those in need (Freeman et al., 2006). Negative emotions can elicit compassion fatigue but positive emotions do not result in this negative reaction. Positive emotions appear to facilitate interaction with one's environment by encouraging 'approach behaviors' (Fredrickson, 2001; 2006). One 
question is whether elevation, one such positive emotion, is related to engagement in interventions to increase prosocial behavior (e.g., organ and tissue donation)? While it has long been understood that negative emotions like anxiety and fear encourage avoidant behaviors, it is likely that elevation will encourage interest in organ donation subject matter. This is because positive emotions are positively related to engagement in activities (Fredrickson, 2001; 2006) and in this study elevation would be used to increase engagement in prosocial behavior subject matter for organ and tissue donation. For the purpose of this study a measure of engagement was included assessing ratings of level of interest in subject area, and how relevant the information felt to the participant.

\section{Cultural Considerations}

The college student population is ideal to introduce organ donation education because of their youth, educational background, level of altruistic motivation, and because mortality is not typically a significant concern for this age-group (Milaniak, 2010). Additionally, Chickering and Kytle (1999) suggested that differences in emotional development and competence occur as college students get older and mature. Thus, experience of elevation will be analyzed by age. Recruitment targeted students in all age groups. Additionally, because women have reported experiencing greater elevation than men in one study (Landis et al., 2009) while no significant gender differences were reported in another study (Freeman et al., 2008) we will aim to recruit an equal number of men and women in the study and will analyze the relationship between gender and elevation, but we will not control for gender. The student population at the University of Rhode Island (URI) has the following 
breakdown of ethnicity: 72\% White; 6\% Hispanic, 5\% Black/African American; 3\% Asian; 0\% American Indian/Alaska Native, and 12\% unreported. URI undergraduates are approximately 55\% female. It is expected that the sample in this study will reflect these demographic proportions. Due to the ethnic breakdown at URI, we did not expect to recruit sufficient participants in order conduct analyses by race/ethnicity. However, the relationship between elevation and race was examined in the analyses for exploratory purposes.

There has been no previous research investigating the specific relationship between mood states and prosocial health behaviors. This study is innovative because it investigated a novel emotion, elevation that has been directly related to prosocial behavior and has expanded the understanding of this emotion in relation to organ donation decision-making.

\section{Current study}

The present experiment was designed to evaluate state elevation (as induced via an internet delivered video clip that has previously been established to elicit elevation) on attitudes and intentions for organ and tissue donation in college student participants. The elevation induction was compared to mirth (positive emotion control) and neutral (control) mood states. TTM-based measures were used to assess organ donation decision-making and stress management, and engagement and trait elevation measures were also collected. Participants had the opportunity to immediately register to be an organ/tissue donor following completion of the survey. A link was provided to the national registry for organ donation. In addition, trait elevation was investigated in relation stress management and well-being. 


\section{Hypotheses}

This study aimed to address the aforementioned gaps in the literature by considering the following hypotheses:

1. Participants in the elevation condition would endorse greater elevation items on the Elevation and Happiness Scale compared to those in mirth and neutral conditions.

2. Participants in the elevation condition would endorse greater Pros, SelfEfficacy, and engagement in organ donation and greater stress management and coping skills compared to those in the mirth, and neutral conditions.

3. Participants in the elevation condition would endorse greater readiness to register as an organ donor compared to those in the mirth, and neutral conditions.

4. Gender would be a significant moderator such that women will score higher on elevation than men.

5. Trait elevation would be positively related to well-being.

6. Trait elevation would be positively related to readiness to become an organ donor. 


\section{CHAPTER 3}

\section{METHODOLOGY}

\section{Participants}

Participants were undergraduate students at the University of Rhode Island recruited via email from introductory psychology courses. Participants were eligible if they were at least 18 years of age and could access the survey on a personal computer. Participants could not use an Apple computer to access the survey as the video content could only be viewed on Windows-based personal computers. Participants received research credit for their participation. Participation in this study was voluntary, anonymous, and in accordance with the ethical guidelines provided by URI's Institutional Review Board. There were no other specified exclusion criteria. Procedure

Participants were recruited from URI's student body in undergraduate courses by the investigator. A mass email was sent to professors of undergraduate courses in order to encourage their students to participate for research credit. The professors then posted the link to the survey online through Sakai (an online education portal used to display information related to classes and other academic information through the University) in order to restrict access to students in their courses.

Measures

All measures were available through the URI Cancer Prevention Research Center. Please refer to appendices A-P for all measures used in this study.

Informed Consent Form. The informed consent form explained the general purpose of study, which was to understand more about organ donation (Appendix A). 
The rights of the participants that were mentioned were: that they must answer each question, but should they choose to not answer, they could stop the study at any time without penalty. Additionally, all information gathered would be kept confidential. Also included in the consent was the general length of the study (20 minutes) and assurance of anonymity of the participant's information was included. It stated that this research project is a requirement of the Doctor of Philosophy Degree in Clinical Psychology at University of Rhode Island. The informed consent specified that participation in this study was voluntary. Additionally, the informed consent mentioned the possibility of discomfort the participant could experience due to disclosing personal information, and that they would receive research credit for participation. Additionally, they were given contact information for the Principal Investigator: Nicole Amoyal in case any participants had questions or concerns about the study. Debriefing would occur per request of the participant. They had the option to contact the Principal Investigator by email when the study was completed.

Demographic Information Form. The demographic information form gathered information regarding the participant's age, gender, grade level in school, religion, and race/ethnicity (Appendix C).

Affect Induction Videos. The video designed to induce elevation was a 7minute video segment of The Oprah Winfrey Show in which a musician pays tribute to his mentor and former music teacher, who had inspired him to be a musician and educator and overcome significant barriers to success (e.g., growing up in a culture of gang activity and violence) (Haidt, 2008). The video induces elevation by illustrating a story line that captures the prosocial behavior of thanking someone that helped the 
main character succeed, and then another prosocial act where that same teachers' current students joined together to thank him in return for helping inspire them to also achieve success despite similar barriers (e.g., another prosocial act on a grander scheme). This video was previously used to elicit elevation in laboratory studies (Silvers \&Haidt 2008; Simone \&Schnall, 2009; Schnall, Roper, \&Fessler, 2010). The mirth video was a 7-minute video clip of a comedian, Demetri Martin, performing a stand-up routine. Mirth was used as one of the comparison conditions to control for the known effects of positive emotions in facilitating positive social interactions. The neutral control video was a 7-minute segment from "The Open Ocean" nature documentary by David Attenborough showing various marine life (1984), similar to the previously one used by Schnall et al., (2010) and Simone et al., (2009). While the exact same 7-minute neutral condition video clip used in the aforementioned studies was unavailable, a similar 7-minute clip from a different portion of the same movie was used.

Validity Check for Videos. Participants in each condition were asked to respond to one question about the content presented in each video in order to ensure they were attentive (Appendix H). Participants in the elevation condition were asked “In this video, what was Fernando given as a surprise?" The correct response was "his students wanted to thank him." Participants in the mirth condition were asked "Who does Demetri Martin think should throw stones?" The correct answer was "people trapped in glass houses." Participants who received the neutral control video were asked "Beluga Whales are sometimes called...?" and the correct response was "Sea 
Marshmallows." Only participants with correct responses were included in the analyses.

Elevation State Questionnaire. A rating scale was used to assess 7 feelings and cognitive appraisals associated with elevation (Appendix I; Haidt, 2003). Participants were asked to report how they felt immediately after watching the video clip, using a scale from 1 (didn't feel at all) to 9 (felt very strongly). Ratings were made from the following items "moved," "uplifted," "optimistic about humanity," "warm feeling in the chest," "want to help others," and "want to become a better person." To assess the effect of condition on general positive affect, participants were also asked to rate how happy and amused they felt, using the same rating scale.

The Elevation Scale. This 13-item scale (Haidt, 2000) is a self-report measure containing questions that are intended to measure the trait-like and habitual experience of the emotion elevation; both frequency and depth (Appendix G). The questionnaire begins with asking the participants to recall approximately how many times per month they come across stories that they have read or heard that describe how people went out of their way to help others. The remaining questions pertain to the effects that these types of stories have on the individual (e.g. "I feel tingles or goosebumps," "It makes me want to tell the story to other people," and "It makes me feel more open and loving towards people in general"). The format of possible participant responses includes never, sometimes, usually, and always.Haidt (personal communication with Jonathan Haidt, March $\left.24^{\text {th }}, 2007\right)$ reported a Cronbach reliability coefficient of .83 . Landis, Sherman, Piedmont, Kirkhart, Rapp, and Bike (2009) reported a reliability coefficient of .80. Landis, Sherman, Piedmont, Kirkhart, Rapp, and Bike investigated 
the psychometric properties of the responses to the elevation scale and reported good incremental validity (overall effect size of elevation $=12.46 \%$ above and beyond personality factors).

Organ Donation Stages of Change Questionnaire. This questionnaire consisted of 6 items to determine participants' decision to become an organ donor at their time of death (Appendix D). All questions had yes or no response options. Additionally, this measure is scored based on an algorithm outlined by Transtheoretical Model of stages of change (Robbins et al., 2001). Precontemplation was defined as not an organ donor and not planning on becoming an organ donor; Contemplation was defined as considering becoming an organ donor in the future, but still ambivalent; Preparation was defined as making the decision to become an organ donor in the near future (within 6 months); Action was defined as already made the decision to become a donor within the past 6months or making the decision within the next 30 days; and Maintenance was defined as having made the decision to become a donor over 6 months ago.

Organ Donation Behavior Change Questionnaire. In order to investigate smaller increments of behavior change decision making because the Stage of Change questionnaire places participants in mutually exclusive categories, three items were included with a ten point response range (from $1=$ not at all to $10=$ extremely) (Appendix M). The three items were"how likely are you to register as an organ donor at the next possible opportunity," "how likely are you to speak with your family about organ donation at the next possible opportunity," and "how likely are you to register with organ donation registry (either at the DMV or online) at the next possible 
opportunity," In addition, one item was used to assess actual behavior change (organ donation registration). This item included "would you like to register as an organ donor now," where participants could respond "yes" or "no."

Organ Donation Registration. Participants who endorsed that they would consider registering as an organ donor at the next possible opportunity were given the option to register as an organ donor at the end of the survey (Appendix O). They were then asked to click "yes" or "no." If "yes," they were given the link to connect them to the U.S. Department of Health and Human Services National registry system online located at http://organdonor.gov/becomingdonor/index.html.

Organ Donation Decisional Balance Questionnaire.This questionnaire consisted of 14 items; 7 Pros (e.g., "becoming an organ donor is one way of doing God's work") and 7 Cons (e.g., "my family would worry about me if I am an organ donor") of becoming and organ and tissue donor (Appendix E). Participants rated the importance of each item in their personal decision about donation intent on a fivepoint scale ranging from (1) not at all important to (5) extremely important (Robbins et al., 2001).

Organ Donation Self-Efficacy Questionnaire.This questionnaire consisted of six items representing confidence to make a decision to become an organ donor (e.g., "I feel pressured by others to become an organ donor") (Appendix F). Participants rated how confident they feel in regards to each item in their personal decision about donation on a five-point scale ranging from (1) not at all confident (5) extremely confident. 
Organ Donation Engagement Questionnaire. This questionnaire consisted of two items to assess engagement and interest in organ donation content (Appendix M). These items were constructed for this survey only and have not been previously tested. The items included "how personally relevant is the subject matter of organ donation to you," and "how interested are you in learning more about organ donation?"

Well-Being.This questionnaire consisted of 9 items to assess well-being (Appendix N). Items included 2 items focusing on current life satisfaction and predicted life satisfaction in 5 years with a 5 -point rating scale $(1=$ not at all satisfied to $5=$ extremely satisfied). Other items included "How are you feeling today" and "How are you functioning today," where responses included a1-10 scale for both items (1- I'm at my worst 10- I'm at my best) and social well-being items ("I feel that there is no one I can share my most private worries and fears," "If I were sick, I could easily find someone to help me with my daily chores," "When I need suggestions on how to deal with a personal problem, I know someone I can turn to," "I don't often get invited to do things with others," "If I wanted to have lunch with someone, I could easily find someone to join me," and "If I needed some help in moving to a new house or apartment, I would have a hard time finding someone to." Response options for the aforementioned items included "definitely true," "probably true," "definitely false," and "probably false."

Stress Management. One item was used to assess Stage of Change for stress management, "stress management includes regular relaxation, physical activity, talking with others, and/or making time for social activities (Appendix N). Do you effectively practice stress management in your daily life?" Response options included, 
"No, and I do not intend to in the next 6 months," "No, but I intend to in the next 6 months," "No, but I intend to in the next 30 days," "Yes, I have been but for less than 6 months," "Yes, I have been for more than 6 months," and "I currently do not have any stress in my life."

\section{Procedure}

Each participant accessed the survey on the internet via Qualtrics, an online survey software company that specializes in social science and consumer research. Participants could complete the survey from any internet-connected Windows based personal computer. Participants completed the consent and survey online. Following consent, participants were randomly assigned to one of the three conditions differentiated by induction of mood state (i.e., elevation, mirth and control). Participants were asked to read an instruction sheet and then completed all baseline measures; the demographic information form, the organ donation Staging, Decisional Balance, and Self-efficacy scales, the Elevation Scale, Engagement Measure, the Well-Being Measure, the Rhode Island Stress and Coping Measure, and the Stress Management Stage assessment. Then all participants viewed one of three videos designed to evoke an elevation, mirth, or neutral affective response based on how they were randomly assigned following consent. After viewing their respective video, participants in all conditions completed the following forms: the Validity Check, the Elevation and Happiness Scale plus negative emotion questions, the organ donation Staging Questionnaire, and the organ donation Decisional Balance Scale, the organ donation Self-Efficacy Scale, the Rhode Island Stress and Coping Measure, the Stress Staging Item, and an Engagement Questionnaire. 


\section{Design and Analysis}

Experimental manipulations were used in this study. Prior to testing the hypotheses of this study, a number of preliminary analyses were conducted in order to make sure assumptions were met. Assumptions for MANOVA were checked and met. A scatter plot of responses from SPSS was used to determine any outliers, linearity, homogeneity of variances, and bi-variate normality. Preliminary correlational analyses for multicollinearity $(>$.90) were used. Elevation experience by age and ethnicity were analyzed by correlational analyses.

The following hypotheses and analyses were used for this study. Hypothesis 1: Participants in the elevation condition would endorse greater elevation items on the Elevation and Happiness Scale compared to those in mirth and neutral conditions. Analysis 1: Means of each state elevation and control state items were used to assess the items that measure elevation and other mood states. This analysis served as the manipulation check as used in prior research (Schnall et al., 2010). Hypothesis 2: Participants in the elevation condition would endorse greater Pros, Self Efficacy, and engagement for organ donation compared to those in the mirth and neutral conditions. Analysis 2: MANOVA was used to assess the relationship between the categorical independent variable emotion condition and the continuous dependent variable's of means on Pros, Self Efficacy, and engagement for organ donation and stress management. The Tukey test was used post-hoc to determine differences between groups. Effect size was calculated using Cohen's d statistical analysis. Hypothesis 3: Participants in the elevation condition would endorse greater readiness to register as an organ donor compared to those in the mirth and neutral conditions. Analysis 3: 
Chi-square analysis was used to assess the relationship between the categorical independent variable of emotion condition and the categorical dependent variables of stage of change for organ donation and for stress management. Effect size was calculated using Cohen's d statistical analysis. Hypothesis 4: Consistent with previous research, there would be a relationship between gender and elevation, such that women would score higher on trait elevation than men. Analysis 4: An independent ttest was conducted to see if elevation scores varied by gender. For all hypotheses, the level of significance was set at $\alpha=.05$ (two tailed). Hypothesis 5: Trait elevation would be positively related to well-being. Analysis 5: Linear Regression was used to determine whether the continuous independent variable trait elevation scores were positively related to continuous dependent variables, life evaluation scores and social well-being scores. Hypothesis 6: Trait elevation would be positively related to readiness to become an organ donor. Analysis 6: ANOVA was used to determine whether the continuous dependent variable elevation scores were positively related to the categorical independent variable of organ donation readiness scores.

Power analysis (G*Power 3.0.10) was utilized to determine the suggested sample size. In order for the MANOVA analysis to obtain a power level of .80 with an alpha level of .05 two-tailed, and assuming small to moderate effect sizes for primary outcomes, G*Power suggested a minimum of 304 participants ( 76 per group) were required for the study. 


\section{CHAPTER 4}

\section{FINDINGS}

Participants. A total of 1,134 participants clicked on the survey, 896 started, and 297 participants' ages $18-59$ years $(M=22, S D=8.38)$ completed the experiment and answered the manipulation check question correctly. Please see Figure 1 for flow chart regarding recruitment and retention. In addition, please see Table 1 for complete demographic data. Baseline group differences were assessed in order to ensure that random assignment was successful and that groups did not differ by baseline measures. There were no baseline demographic differences by group. No group differences were found regarding Decisional Balance Pros $F(2,294)=.15(p=.86)$, $\eta^{2}=.001$ and Confidence $F(2,294)=.13(p=.88), \eta^{2}=.001$. No group differences were found for Stage of Change $\chi^{2}(6)=1.97, p=.92$ indicating no significant association between baseline organ donation stage and emotion condition group. Thus, analyses did not have to be adjusted to account for potential covariation. Correlations for all study variables can be found in Table 2 . 
Figure 1. Flow Chart of Recruitment and Retention

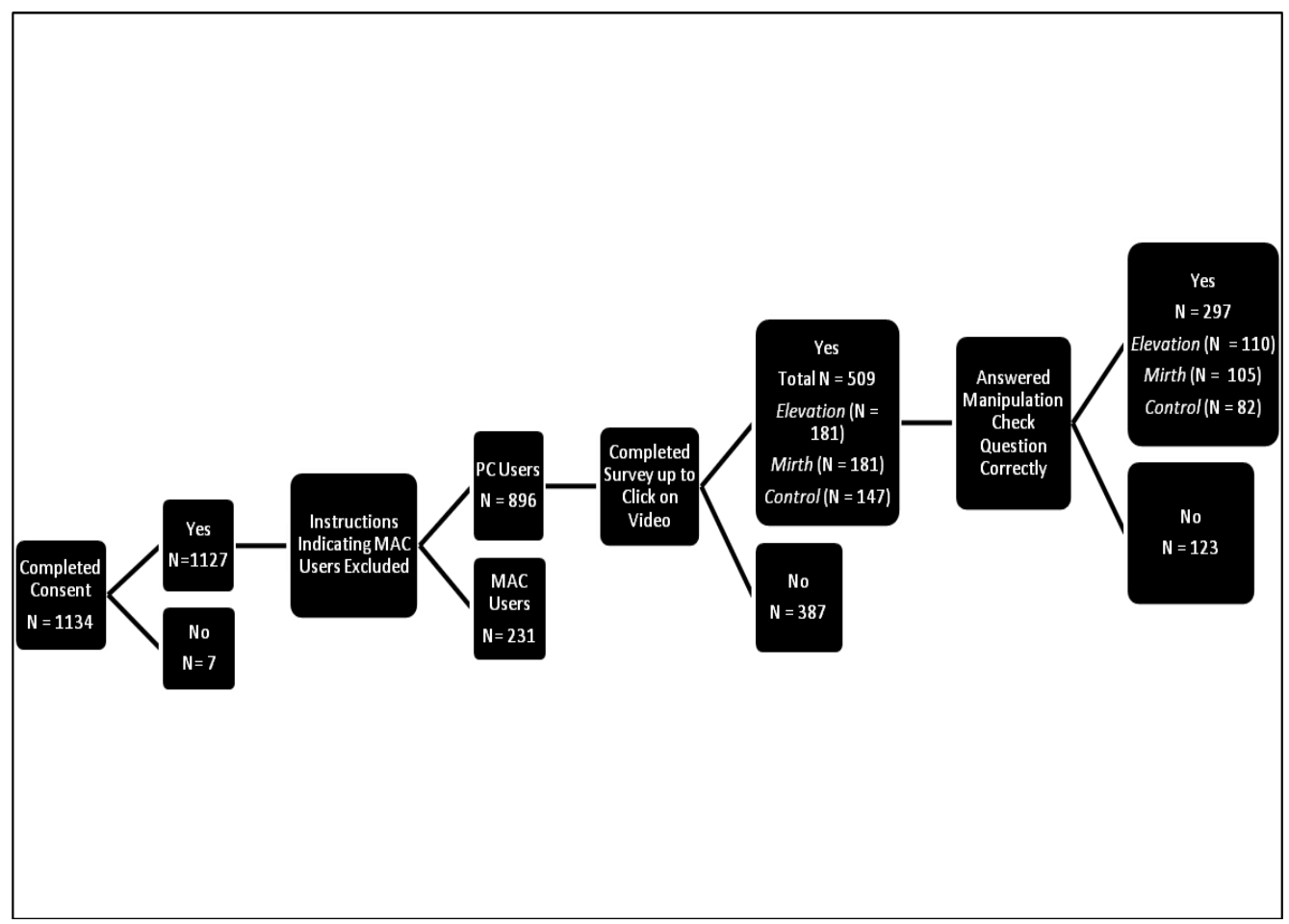


Table 1. General Demographic Characteristics of the Participants

\begin{tabular}{|c|c|c|}
\hline Characteristic & Frequency & Percent \\
\hline \multicolumn{3}{|l|}{ Gender } \\
\hline Male & 88 & 29.6 \\
\hline Female & 209 & 70.4 \\
\hline \multicolumn{3}{|c|}{ Age $(M=22, S D=8.38)$} \\
\hline 18 & 55 & 18.5 \\
\hline 19 & 85 & 28.6 \\
\hline 20 & 61 & 20.5 \\
\hline 21 & 53 & 17.8 \\
\hline 22 & 16 & 5.4 \\
\hline 23 & 9 & 3.0 \\
\hline $24-34$ & 11 & 3.6 \\
\hline $35-59$ & 7 & 2.1 \\
\hline \multicolumn{3}{|l|}{ Ethnicity } \\
\hline Black & 17 & 5.7 \\
\hline Asian & 9 & 3.0 \\
\hline White & 242 & 81.5 \\
\hline Hispanic & 19 & 6.4 \\
\hline Pacific Islander & 0 & 0 \\
\hline Other & 10 & 3.4 \\
\hline \multicolumn{3}{|l|}{ School Year } \\
\hline Freshman & 112 & 37.7 \\
\hline Sophomore & 57 & 19.2 \\
\hline Junior & 70 & 23.6 \\
\hline Senior & 51 & 17.2 \\
\hline Other & 7 & 2.4 \\
\hline \multicolumn{3}{|l|}{ Religion } \\
\hline Catholic & 134 & 45.1 \\
\hline Protestant & 30 & 10.1 \\
\hline Jewish & 9 & 3.0 \\
\hline Atheist & 20 & 6.7 \\
\hline Agnostic & 20 & 6.7 \\
\hline Muslim & 1 & 0.3 \\
\hline Other & 83 & 27.9 \\
\hline
\end{tabular}


Table 2. Correlation Matrix of Main Study Constructs

\begin{tabular}{|c|c|c|c|c|c|c|c|c|c|c|c|}
\hline & Gender & Race & $\begin{array}{c}\text { Pre } \\
\text { CONF }\end{array}$ & $\begin{array}{l}\text { Pretest } \\
\text { PROS }\end{array}$ & $\begin{array}{c}\text { Trait } \\
\text { Elevation }\end{array}$ & $\begin{array}{c}\text { State } \\
\text { Elevation }\end{array}$ & $\begin{array}{c}\text { Post } \\
\text { PROS }\end{array}$ & $\begin{array}{c}\text { Post } \\
\text { CONF }\end{array}$ & $\begin{array}{c}\text { Post } \\
\text { Engage }\end{array}$ & $\begin{array}{c}\text { Social } \\
\text { Wellbeing }\end{array}$ & $\begin{array}{l}\text { Organ } \\
\text { staging }\end{array}$ \\
\hline Gender & - & & & & & & & & & & \\
\hline Race & -.01 & - & & & & & & & & & \\
\hline $\begin{array}{l}\text { Pre } \\
\text { CONF }\end{array}$ & -.04 & -.03 & - & & & & & & & & \\
\hline $\begin{array}{l}\text { Pre } \\
\text { PROS }\end{array}$ & $-.19 * *$ & -.03 & $.12^{*}$ & - & & & & & & & \\
\hline $\begin{array}{l}\text { Trait } \\
\text { Elevation }\end{array}$ & $-.33 * *$ & -.01 & .02 & $.45^{* *}$ & - & & & & & & \\
\hline $\begin{array}{l}\text { State } \\
\text { Elevation }\end{array}$ & -.12 & -.01 & -.01 & $.12 *$ & $.29 * *$ & - & & & & & \\
\hline $\begin{array}{l}\text { Post } \\
\text { PROS }\end{array}$ & $-.25 * *$ & -.05 & .09 & $.65 * *$ & $.53 * *$ & $.22 * *$ & - & & & & \\
\hline $\begin{array}{l}\text { Post } \\
\text { CONF }\end{array}$ & -.67 & .03 & $.37 * *$ & $.23 * *$ & $.15 * *$ & -.02 & $.24 * *$ & - & & & \\
\hline $\begin{array}{l}\text { Post } \\
\text { Engage }\end{array}$ & $-.27 * *$ & -.01 & .01 & $.46^{* *}$ & $.35 * *$ & $.20 * *$ & $.51 * *$ & .10 & - & & \\
\hline $\begin{array}{l}\text { Social } \\
\text { Wellbeing }\end{array}$ & .10 & $.12 *$ & -.01 & -.11 & .05 & .04 & $-.17 * *$ & -.03 & -.10 & - & \\
\hline $\begin{array}{l}\text { Organ } \\
\text { staging }\end{array}$ & $-.12 *$ & .03 & .08 & $.42 * *$ & $.23 * *$ & -.02 & $.36 * *$ & $.20 * *$ & $.28 * *$ & -.06 & - \\
\hline
\end{tabular}

Note: $\mathrm{N}=297 ; *=\mathrm{p}<.05, * *=\mathrm{p}<.01$ 
Manipulation Check.Participants were randomly assigned to one of three emotion conditions. The control (neutral emotion) condition included 82 participants. The mirth (positive emotion control) condition included 105 participants. The elevation condition (experimental condition) included 110 participants. Table 3 presents frequencies of participants per experimental condition. The sample size per experimental condition exceeded minimum requirements for statistical power.

Table 3. Participants per Condition

\begin{tabular}{lccc}
\hline Emotion Condition & & Frequency & Percent \\
\hline Elevation & Male & 32 & \\
& Female & 78 & \\
Mirth & Total & 110 & 37.0 \\
& Male & 37 & \\
& Female & 68 & \\
Neutral Control & Total & 105 & 35.4 \\
& Male & 18 & \\
& Female & 64 & \\
& Total & 82 & 27.6 \\
\hline Note. N=297 & &
\end{tabular}

Prior studies have analyzed the elevation state measure at the item level to serve as a manipulation check. As a novel approach, both the item level and total elevation state scale scores were used in the analyses. Principal Component Analysis yielded a two factor solution that accounted for $85 \%$ of the total variance. The varimax rotated component matrix yielded seven items that loaded onto Factor 1 (all elevation state items; loadings ranged from .79 to .95). Both of the control items loaded onto Factor 2 (happy $=.67$ and amused $=.96$ ). As predicted, participants in the elevation 
condition endorsed significantly greater total state elevation $(M=41.38)$ compared to neutral control $(M=23.95)$ and mirth $(M=23.94)$ groups $F(287)=76.84, p=.00, \eta^{2}$ $=.35$. The elevation scale demonstrated good internal consistency $(\alpha=.95)$.

At the item level, participants in the elevation condition as compared to the participants in the mirth and neutral control conditions, reported higher ratings on all items indicative of elevation (see Table 4 for means). Specifically, they gave higher ratings for feeling moved, $F(2,287)=79.64, p=.00, \eta^{2}=.36$; uplifted, $F(2,287)=$ $42.72, p=.00, \eta^{2}=.23$; optimistic about humanity, $F(2,287)=43.52, p=.00, \eta^{2}=.23$; warm feelings in the chest, $F(2,287)=51.84, p=.00, \eta^{2}=.26$; wanting to help others, $F(2,287)=80.52, p=.00, \eta^{2}=.36$; wanting to become a better person, $F(2,287)=$ $64.04, p=.00, \eta^{2}=.31$. In contrast, the mirth group differed significantly from the elevation and neutral conditions in reported amusement, $F(2,287)=19.59, p=.00, \eta^{2}$ $=.12$. It should be noted that all groups differed significantly on feeling happy, with participants in the elevation condition reported the highest ratings, followed by the mirth group, and both were significantly 'happier' than the neutral control. In sum, the Oprah clip effectively induced the desired emotion of elevation and the comedy clip effectively induced the desired emotion of mirth.

Gender and Elevation. As predicted, there was a significance difference in the scores for trait elevation such that women reported greater elevation $(M=26.28, \mathrm{SD}$ $=5.98)$ than men $(\mathrm{M}=21.83, \mathrm{SD}=5.57) ; t(297)=5.98 ; p<.01)$. Women reported significantly greater scores on total state elevation $\left(\mathrm{F}(288)=3.84 ; p<.05, \eta^{2}=.01\right)$ and all state elevation and control items. Women reported greater feelings of moved, F $(107)=11.81 ; p<.01, \eta^{2}=.10$, uplifted, $\mathrm{F}(107)=11.13, p<.01, \eta^{2}=.09$, amused, $\mathrm{F}$ 
$(107)=9.17, p<.01, \eta^{2}=.08$, optimistic, $\mathrm{F}(107)=24.34, p<.01, \eta^{2}=.18$, happy, $\mathrm{F}$ $(107)=12.25, p<.01, \eta^{2}=.10$, warm, $\mathrm{F}(107)=11.22, p<.01, \eta^{2}=.10$, wanting to help others, $\mathrm{F}(107)=11.02, p<.01, \eta^{2}=.09$, and wanting to be a better person, $\mathrm{F}$ $(107)=9.97, p<.01, \eta^{2}=.09$. Please refer to Table 5 for mean values of ratings of elevation state items by gender.

State and Trait Elevation. The state elevation items were summed to derive a total state elevation score. Results indicated that total state elevation was positively correlated with total trait elevation $\mathrm{r}(290)=.29, p<.01$. 
Table 5.Means for Self-Ratings of Elevation State Items by Gender.

\begin{tabular}{|c|c|c|c|c|c|c|c|c|c|}
\hline \multirow[b]{2}{*}{ Condition } & \multicolumn{8}{|c|}{ Item } & \multirow[t]{2}{*}{ Tota } \\
\hline & Moved & Uplifted & Amused & $\begin{array}{c}\text { Optimistic } \\
\text { About } \\
\text { Humanity }\end{array}$ & $\begin{array}{c}\text { Warm } \\
\text { Feeling in } \\
\text { the Chest }\end{array}$ & $\begin{array}{c}\text { Wanting } \\
\text { to Help } \\
\text { Others }\end{array}$ & $\begin{array}{c}\text { Wanting } \\
\text { to } \\
\text { Become a } \\
\text { Better } \\
\text { Person } \\
\end{array}$ & Hарру & \\
\hline Women & 7.30 & 7.21 & 5.52 & 7.45 & 6.99 & 7.37 & 7.45 & 7.38 & 31.38 \\
\hline Men & 6.03 & 5.97 & 4.09 & 5.69 & 5.47 & 6.00 & 6.16 & 6.00 & 27.83 \\
\hline
\end{tabular}


Table 4.Means for Self-Ratings of Elevation State Items.

\begin{tabular}{|c|c|c|c|c|c|c|c|c|c|}
\hline \multirow[b]{2}{*}{ Condition } & \multicolumn{8}{|c|}{ Item } & \multirow{2}{*}{$\begin{array}{c}\text { Total } \\
\text { State } \\
\text { Elevation }\end{array}$} \\
\hline & Moved & Uplifted & Amused & $\begin{array}{c}\text { Optimistic } \\
\text { About } \\
\text { Humanity }\end{array}$ & $\begin{array}{l}\text { Warm } \\
\text { Feeling in } \\
\text { the Chest }\end{array}$ & $\begin{array}{l}\text { Wanting } \\
\text { to Help } \\
\text { Others }\end{array}$ & $\begin{array}{c}\text { Wanting to } \\
\text { Become a } \\
\text { Better } \\
\text { Person }\end{array}$ & Happy & \\
\hline \multirow[t]{2}{*}{ Elevation } & 6.93 & 6.85 & 5.10 & 6.91 & 6.57 & 7.01 & 7.11 & 7.03 & 41.38 \\
\hline & (1.83) & (1.84) & $(2.32)$ & (1.87) & $(2.24)$ & $(2.01)$ & (1.98) & (1.93) & (10.52) \\
\hline \multirow[t]{2}{*}{ Mirth } & 3.46 & 4.64 & 6.59 & 4.86 & 3.79 & 3.38 & 3.81 & 5.87 & 23.94 \\
\hline & $(2.47)$ & $(2.58)$ & (2.34) & $(2.39)$ & $(2.46)$ & $(2.37)$ & $(2.65)$ & $(2.42)$ & $(12.51)$ \\
\hline \multirow{2}{*}{$\begin{array}{l}\text { Neutral } \\
\text { Control }\end{array}$} & 3.83 & 4.09 & 4.67 & 4.21 & 3.64 & 4.07 & 4.11 & 4.53 & 23.95 \\
\hline & (2.14) & $(2.14)$ & $(2.04$ & (1.97) & $(2.12)$ & $(2.13)$ & $(2.22)$ & $(2.27)$ & (11.47) \\
\hline
\end{tabular}

Note. Standard deviations are given in parentheses. 
Elevation and Decision Making for Behavior Change in Organ Donation

Analyses. Four sets of analyses were conducted. First, consistent with the methodology utilized in prior studies, group differences were analyzed with all 297 participants by experimental condition. Second, all analyses were conducted separately by gender to see if gender was driving results. No significant differences were found with women or men only and as such will not be discussed further. Fourth, two-way ANOVAs were used to explore all dependent variables by stage and experimental condition. In the fourth set of analyses, no interaction effect was noted. Furthermore, the results for the first and fourth set of analyses were comparable, thus, only the first set of analyses will be described in greater detail as follows.

Stage Distribution. Atbaseline, the majority of participants were in Action and Precontemplation stages for becoming and organ and tissue donor; $45.1 \%$ and $35.7 \%$ accordingly. Table 6 shows the staging distribution of participants in the sample at baseline by gender. There were no significant differences between gender by stage $\chi^{2}$ $=5.73, p=.13$.

Table 6.Baseline Stage Distribution by Gender.

\begin{tabular}{rccccc}
\hline Stage & Precontemplation & Contemplation & Preparation & Action & Total \\
\hline Female & 68 & 14 & 24 & 103 & 209 \\
Male & 38 & 5 & 14 & 31 & 88 \\
Total & $\mathbf{1 0 6}$ & $\mathbf{1 9}$ & $\mathbf{3 8}$ & $\mathbf{1 3 4}$ & $\mathbf{2 9 7}$ \\
\hline
\end{tabular}

Note: $\mathrm{N}=297$.

Decisional Balance. State elevation was not predictive of participants' posttest endorsement of Pros, $F(293)=.21, p=.81$. However, as indicated in Table 7 
below, there were several significant correlations between elevation state items and Decisional Balance items. In sum, there was a trend toward significant associations at the item level between constructs, but results did not remain significant in terms of total scores. Please refer to Table 7 for correlations of Decisional Balance items by experimental condition. 
Table 7. Decisional Balance Items by Elevation State Items per Condition

\begin{tabular}{|c|c|c|c|c|c|c|c|}
\hline Moved & Uplifted & Amused & Optimistic & Happy & $\begin{array}{l}\text { Warm } \\
\text { feeling } \\
\text { in } \\
\text { Chest }\end{array}$ & $\begin{array}{l}\text { Wanting } \\
\text { to help } \\
\text { others }\end{array}$ & $\begin{array}{l}\text { Wanting } \\
\text { to } \\
\text { become a } \\
\text { better } \\
\text { person }\end{array}$ \\
\hline
\end{tabular}

If I become an organ donor, I will not be 'whole' in my life after death? (CON)

$\begin{array}{rcccccccc}\text { Elevation } & .05 & .06 & .11 & -.02 & -.01 & .06 & .05 & .04 \\ \text { Mirth } & .18 & .25^{*} & .13 & .26^{* *} & .11 & .29 * * & .34^{* *} & .29 * * \\ \text { Neutral Control } & .14 & .13 & -.01 & .24 * * & .04 & .15 & .18 & .14\end{array}$

Organ donation would allow something positive to come out of my death. (PRO)

$\begin{array}{rcccccccc}\text { Elevation } & .30^{* *} & .30^{* *} & .09 & .26^{* *} & .36^{* *} & .33^{* *} & .38^{* *} & .40^{* *} \\ \text { Mirth } & .13 & .07 & .03 & .15 & .10 & .05 & .15 & .21^{*} \\ \text { Neutral Control } & .05 & .08 & .11 & .01 & .19 & .06 & .08 & .06\end{array}$

Becoming an organ donor would upset my family. (CON)

$\begin{array}{rllllllll}\text { Elevation } & .01 & -.03 & .18 & .02 & -.10 & -.05 & -.01 & .05 \\ \text { Mirth } & .03 & .05 & -.11 & -.01 & -.03 & .04 & -.00 & .07 \\ \text { Neutral Control } & .30^{* *} & .33^{* *} & .20 & .40^{* *} & .18 & .41^{* *} & .36^{* *} & .35^{* *}\end{array}$

If I become an organ donor I won't have control over who receives my organs. (CON)

$\begin{array}{rcccccccc}\text { Elevation } & -.01 & -.02 & .04 & -.09 & -.08 & -.05 & -.06 & -.02 \\ \text { Mirth } & .10 & .11 & -.04 & .11 & .03 & .13 & .17 & .16 \\ \text { Neutral Control } & .22 * & .24 * & -.04 & .22 * & .07 & .20 & .29 * * & .27 *\end{array}$

Becoming an organ donor is one way of doing God's work. (PRO)

$\begin{array}{rcccccccc}\text { Elevation } & .20 * & .19 & .06 & .08 & .22 * & .19 & .20 * & .23 * \\ \text { Mirth } & .14 & .19 & .05 & .19 & .03 & .18 & .11 & .14 \\ \text { Neutral Control } & .18 & .20 & -.07 & .14 & .09 & .14 & .15 & .06\end{array}$


My family would worry about me if I am an organ donor. (CON)

$\begin{array}{rllllllll}\text { Elevation } & .06 & .04 & .08 & .07 & .03 & .09 & .07 & .09 \\ \text { Mirth } & .02 & .11 & -.05 & .05 & .06 & .08 & .01 & .12 \\ \text { Neutral Control } & .33 * * & .35 * * & .11 & .35 * * & .12 & .34 * * & .34 * * & .27 *\end{array}$

Becoming an organ donor is the right thing to do. (PRO)

$\begin{array}{rrrrrrrrr}\text { Elevation } & .24 * & .23 * & .16 & .21 * & .31 * & .23 * & .29 * * & .29 * * \\ \text { Mirth } & .17 & .12 & .19 * & .20 * & .19 & .15 & .22 * & .18 \\ \text { Neutral Control } & .03 & .07 & .06 & .00 & .17 & .11 & .07 & .10\end{array}$

My family disapproves of organ donation. (CON)

$\begin{array}{rrrrrrrrr}\text { Elevation } & .03 & -.02 & .19 & -.00 & -.05 & -.03 & -.03 & -.01 \\ \text { Mirth } & .10 & .12 & -.05 & .10 & .05 & .16 & .12 & .21^{*} \\ \text { Neutral Control } & .23^{*} & .24 * & .03 & .28^{*} & .10 & .35^{* *} & .27^{*} & .26^{*}\end{array}$

It would help my family to know my wishes to become an organ donor in the event of my death. (PRO)

$\begin{array}{rrrrrrrrr}\text { Elevation } & .23 * & .19 & .10 & .11 & .25 * & .21 * & .22 * & .24 * \\ \text { Mirth } & -.10 & -.06 & .11 & .02 & .02 & .06 & -.01 & -.06 \\ \text { Neutral Control } & .13 & .18 & .17 & .10 & .34 * * & .12 & .13 & .14\end{array}$

There is a special need for organ donation in my race. (PRO)

$\begin{array}{rrrrrrrrr}\text { Elevation } & .11 & .05 & .13 & .06 & .12 & .18 & .18 & .20 * \\ \text { Mirth } & -.10 & .00 & -.05 & .03 & -.09 & -.06 & .05 & -.02 \\ \text { Neutral Control } & .00 & .06 & -.12 & .03 & .04 & .15 & .05 & .07\end{array}$

Thinking about donating my organs after I die makes me uncomfortable. (CON)

$\begin{array}{rrrrrrrrr}\text { Elevation } & -.03 & -.01 & .06 & -.00 & -.04 & .05 & -.03 & -.05 \\ \text { Mirth } & .03 & .05 & .04 & .00 & .03 & .11 & .14 & .14 \\ \text { Neutral Control } & .15 & .17 & .00 & .26^{*} & .04 & .27 * & .28^{*} & .24 *\end{array}$


Organ donation is against my religious beliefs. (CON)

$\begin{array}{rcccccccc}\text { Elevation } & .10 & .06 & .20^{*} & .02 & -.06 & .01 & .02 & .02 \\ \text { Mirth } & .10 & .12 & -.03 & .11 & -.01 & .12 & .17 & .10 \\ \text { Neutral Control } & .25^{*} & .23^{*} & .03 & .22^{*} & .05 & .31^{* *} & .25^{*} & .25^{*}\end{array}$

If I am an organ donor, I might prevent another family from losing a loved one. (PRO)

$\begin{array}{rcccccccc}\text { Elevation } & .28 * * & .27 * * & .05 & .18 & .37 * * & .30^{* *} & .32 * * & .34 * * \\ \text { Mirth } & .03 & .04 & .17 & .14 & .18 & .06 & -.02 & .11 \\ \text { Neutral Control } & .00 & .02 & .11 & -.10 & .22 & -.01 & .06 & .08\end{array}$

I would show that I am responsible by becoming an organ donor. (PRO)

\begin{tabular}{rcccccccc} 
Elevation & $.32 * *$ & $.28 * *$ & $.25 *$ & .19 & $.31 * *$ & $.27 * *$ & $.27 * *$ & $.31 * *$ \\
Mirth & .18 & $.21^{*}$ & .01 & $.39 * *$ & .17 & $.20^{*}$ & $.29 * *$ & $.38^{* *}$ \\
Neutral Control & $.27 *$ & $.30 * *$ & .04 & .21 & .19 & $.22 *$ & $.30 * *$ & $.25 *$ \\
\hline
\end{tabular}

Note. $* *$ Indicates significant at $\mathrm{p}=.01, *$ indicates significance at $\mathrm{p}=.05$. 
Self-efficacy. State elevation was not predictive of participants' post-test endorsement of self-efficacy related to becoming an organ and tissue donor; $F(293)=$ $.86, p=.43$. Due to insignificant results, further analysis of self-efficacy by experimental condition was not conducted.

Engagement. State elevation was not predictive of engagement in organ donation subject matter. Specifically, items included "How personally relevant is the subject matter of organ donation to you?" $F(293)=.89, p=.41$, and "How interested are you in learning more about organ donation?" $F(293)=.67, p=.51$.

Stage of Change. Analyses to determine Stage of Change were used only to determine Stage of Change movement specifically for Precontemplation to Contemplation and Contemplation to Preparation. Due to the post-test immediately following the video clip, it was not possible for participants to move into Action. Thus, those in Action at baseline were not included in these analyses. Post-test analyses revealed that organ donation Stage of Change did not differ by emotion condition for those in Precontemplation $\left(\chi^{2}(2)=4.59, p=.10\right)$ and Contemplation $\left(\chi^{2}\right.$ $(2)=5.40, p=.07)$ at baseline. Specifically, participants in the elevation condition that were in Precontemplation were not more likely to think about becoming an organ donor in the next six months. Additionally, participants in the elevation condition and in Contemplation were not more likely to consider becoming an organ donor within the next 30 days. While statistically, the results were not significant, the results suggested a trend toward significant differences between group in the hypothesized 
direction. The raw scores yielded greater numbers in the elevation condition compared to the control conditions. Please refer to Table 8 for raw values.

For further investigation Precontemplation and Contemplation were combined together to see an overall change was significant. Overall change was defined as participants saying that they are now planning on making the decision within the next 6 months (for Precontemplation at baseline) or 30 days (for Contemplation at baseline). Significant group differences $\left(\chi^{2}(2)=8.54, p<.05\right)$ were found such that participants in the elevation group $(n=14 ; 29.2 \%)$ reported greater overall change compared to the neutral group $(n=3 ; 8.6 \%)$ and the positive emotion group $(n=4$; $9.5 \%)$.

Organ Donation Behavior Change Questionnaire. State elevation was not predictive of incremental items assessing behavior change. Specifically, items included "how likely are you to register as an organ donor at the next possible opportunity," $F(123)=.07, p=.79$, "how likely are you to speak with your family about organ donation at the next possible opportunity," $F(295)=.16, p=.69$ and "how likely are you to register with organ donation registry (either at the DMV or online) at the next possible opportunity," $F(17)=.00, p=.95$. 
Table 8.Pre-test Stage and Post-Test Intentions by Condition.

Are you planning to make the decision to become an organ donor in the next 6 months?

\begin{tabular}{|c|c|c|c|c|}
\hline \multirow[t]{2}{*}{ Precontemplation } & & Elevation & Mirth & $\begin{array}{l}\text { Neutral } \\
\text { Control }\end{array}$ \\
\hline & YES & 10 & 3 & 3 \\
\hline & NO & 31 & 34 & 25 \\
\hline
\end{tabular}

Are you planning to make the decision to become an organ donor in the next 30 days?

Contemplation Elevation Mirth

Neutral Control YES 4 1 0 NO 2

4 4

Organ Donation Registration.Participants that responded "yes" to "would you like to register as an organ donor now" were given the opportunity to do so at the end of the study. No significant differences were found between elevation and control conditions in their willingness to volunteer to become an organ donor at the end of the study $\left.\chi^{2}(2)=.80, p=.67\right)$. However, eight participants registered to become organ donors at the end of this study. Please refer to Table 9 for the raw values.

Table 9.Actual Participant Registration by Group.

\begin{tabular}{cccc}
\hline & Elevation & Mirth & Neutral Control \\
\hline Yes & 1 & 2 & 3
\end{tabular}


No $\quad 0 \quad 0 \quad 2$

Note. $N=8$.

Elevation and Decision Making for Behavior Change in Stress Management

Stage of Change. Baseline Stage of Change for stress management did not differ by emotion condition; $\chi^{2}(10)=8.78 ; p=.55$. Contrary to prediction, post-test analysis indicated that readiness for stress management was not associated with emotion condition; $\chi^{2}(10)=14.59 ; \mathrm{p}=.15$.

\section{Trait Elevation}

Trait Elevation and Well-being.Contrary to prediction, participants' trait elevation did not predict feeling and functioning well-being; $F(295)=.09 ; p=.77$. Participants' trait elevation did not predict social well-being; $F(294)=.76 ; p=.38$.

Trait Elevation and Organ Donation Stage. As predicted, participants' trait elevation was significantly related to baseline readiness to become an organ donor; $F$ $(291)=3.77, p<.01, \eta^{2}=.06$; such that participants in Precontemplation reported significantly less trait elevation compared to those participants in Action. 


\section{CHAPTER 5}

\section{CONCLUSION}

The findings in this experiment contribute to research on moral elevation in several ways. First, the results support that the habitual experience of elevation over time (trait elevation) is positively related to readiness to become an organ and tissue donor, expanding prior research supporting elevation and altruistic behavior towards a specific prosocialhealth behavior. Second, elevation was successfully induced via online video administration, which has important practical implications for future research and intervention development. Third, a newly developed elevation state scale demonstrated good psychometric properties which support using the total state elevation score in addition to separate item-level analyses. Fourth, one of the goals of this experiment was to understand whether and how a specific prosocial emotional state would impact prosocial health behavior decision-making related to becoming an organ and tissue donor based on prior studies that supported that elevation increased prosocial behavior in laboratory based studies. Our experiment supported that elevation was significantly related to increased overall organ donation intentions for participants when they were grouped together (Precontemplation and Contemplation stages) at baseline. Our experiment did not support our hypotheses as elevation being significantly related to an increase readiness, Pros, Self-efficacy, and organ donation intentions in the analytic format originally hypothesized and alternative explanations are discussed. Fourth, consistent with prior studies, it was supported in that; women would score higher on elevation than men further solidifying this widespread finding. Finally, despite research supporting that prosocial emotional experiences related to 
prosocial behavior have positive effects on health and well-being (Poulin, 2013), trait elevation did not predict well-being in this study.

Trait elevation was significantly related to readiness to become an organ and tissue donor. Participants in Precontemplation reported significantly lower endorsement of trait elevation compared to those in Action. This finding suggests that greater experiences of elevation are related to an actual prosocial health behavior. It may be that repeated experiences of moral elevation have an impact on prosocial health behavior. Alternatively, greater experiences of elevation may be resultant of participation in prosocial behavior (such as becoming an organ and tissue donor). For example, trait elevation is positively and significantly related to Big Five personality characteristics, especially Openness to Experience (Landis et al., 2010). Thus, those more open to experiences may participant in a greater number of prosocial experiences which increases the likelihood to experience elevation. The current study replicates that trait elevation is positively related to prosocial behavior but further expands the previous research to support the positive relationship between elevation and a specific prosocialhealth behavior; which has not formerly been examined. Furthermore, results yield that the relationship between elevation and organ donation intentions exists, however, the extent to which elevation can influence organ and tissue donation intentions remains to be fully understood.

It was predicted that a video that had previously been shown to induce elevation in laboratory studies would effectively elicit elevation, only this time by delivery to participants on personal computers via the internet. This induction was compared to videos designed to induce mirth or to serve as a control. Elevation was 
successfully induced via a 7-minute internet-delivered video clip, through online survey distribution. Participants in the elevation video condition endorsed greater elevation items on the Elevation and Happiness Scale compared to those in the mirth and neutral conditions. The elevation induction produced mean ratings of state elevation that were between 6.57 and 7.11. These item means were comparable to prior ratings in a lab-based experimental condition elicited by Schnall et al. (2011).

This experiment supports future research investigating the moral emotion elevation to utilize technological platforms that are more readily accessible to participants in order to increase sample size, potential reach for participation, and number of studies investigating this emotion. In addition, being able to elicit moral elevation via computer-delivered videos provides a low-cost and generalizeable approach to research, considering the limitations to generalizability within laboratorybased experiments. While, the current experiment could not control whether participants watched the video, the video manipulation check provided support that a large sample of participants did watch and were engaged with the video.

To the best of our knowledge, the state elevation scale's factor structure has not been investigated prior to this study. Prior factor analyses on the trait elevation scale (10 items) yielded a two factor structure. Factor 1 consisted of items representing 'connectedness to others' (e.g., "I feel like I want to do something good too") and Factor II consisted of physiological items (“choked up") (Landis et al., 2010). In this study, the state elevation scale yielded good internal consistency suggesting that the scale is valid assessment of state elevation. However, factor analyses in the current study supported a one factor model that included all elevation items. It should be noted 
that the trait elevation scale and the state elevation scale differ in terms of the items they assess. Although similar, the state elevation scale includes only six elevation items, only one of which represents a physiological component.

It was hypothesized that state elevation would be positively related to Stage of Change, endorsement of Pros, Self Efficacy, and engagement, and negatively related to endorsement of Cons. Significant relationships between Pre and Post organ donation intentions were found when Precontemplation and Contemplation stages were combined at baseline. However, the sample did not include enough Pre-Action participants to detect potential significant relationships for participants in separate stages. The aforementioned results provide support for an overall trend of elevation being significantly related to increases in organ donation intentions.

No significant relationships were found between state elevation and Stage of Change, Decisional Balance, Self Efficacy, and engagement for organ donation compared to those in the neutral and mirth conditions as originally proposed. More studies are needed to better understand the potential behavioral antecedents related to the experience of the powerful motion elevation. In prior studies, moral elevation was found to increase willingness to engage in prosocial acts in laboratory based settings (Aquino et al., 2012; Schnall et al., 2010; Schnall et al., 2011; Freeman et al., 2009). In this study, specific markers of behavior change were investigated to better understand the mechanisms of action that occur and how elevation can relate to prosocialhealthbehavior change in a naturalistic setting. Overall, elevation did not predict overall Pros and Self-Efficacy. According to the TTM, increasing Pros is associated with behavior change (Prochaska et al., 1994; Hall\&Rossi, 2008). While it 
was predicted that inducing elevation may have a potential synergistic effect by increasing participant's Pros, and thus, increasing readiness to become an organ donor, no such effect was found. This result could be due to elevation not being sufficiently induced in the participants to lead to behavior change. However, in post-hoc analyses for the elevation experimental condition, several Pros items were positively related to greater endorsement of elevation that were not significant in the control conditions. For example, "if I am an organ donor, I might prevent another family from losing a loved one," and "organ donation would allow something positive to come out of my death" were two items that were significantly related to greater endorsement of state elevation items. While it is not customary to separate the Decisional Balance Scale into item-level analyses, this type of analysis was done for exploratory purposes to identify any trending towards changes in decision making.

Regarding the other TTM constructs, several Cons items were significantly endorsed by the neutral condition and not by the elevation and positive emotion condition (e.g., "my family would worry about me if I am an organ donor," and"if I become an organ donor I won't have control over who receives my organs"); which suggests a valence effect of positive emotions on endorsement of Cons. However, interpretation of results at the item level is purely speculative and would require further study. This effect may potentially be explained by Fredrickson's (2001) Broaden and Build Theory such that a positive emotional state expanded participants' mindsets in a positive way allowing them to feel less influenced by negative factors associated with organ donation. In terms of Self-efficacy, elevation was not related to confidence in becoming an organ and tissue donor. While it was expected that 
elevation would increase ratings of Self-efficacy, the alternative findings need further investigation.

In this study, moral state elevation was not related to actual prosocial health behavior change. Participants in the elevation condition were not more likely to register as an organ donor at the end of the study. Findings indicated that the moral state of elevation was not powerful enough to elicit behavior change as measured by readiness to register as an organ and tissue donor in an online environment. Eight participants actually registered to become an organ donor, which may be explained by mere measurement effects (Godin, Sheeran, Connor, \&Germain, 2008). Mere measurement effects have been found in another prosocial health behavior (e.g., blood donation) and suggested that just asking questions about blood donation increased the desired behavior.

In previous research moral state elevation was related to increased helping behavior in laboratory based experiments (Schnall et al., 2010; Schnall et al., 2011; Freeman et al., 2009). This study investigated whether this relationship could translate to a specific prosocial health behavior, organ and tissue donation in a non-laboratory context. The question remains as to whether significant findings as indicated in prior research are confined to laboratory settings. While state elevation was not predictive of readiness to become an organ and tissue donor, results indicated trending towards significant group differences for those in Precontemplation and Contemplation planning on making the decision to become an organ donor within the next 30 days. The most recent studies regarding elevation have investigated ways of maximizing the experience of elevation (Schnall\& Roper, 2011) and have shown that including a self- 
affirmation exercise (Schnall\& Roper, 2011) and including a story where the recipient of the moral act is of good character and the act of moral goodness requires great effort (Aquino et al., 2012) have increased feeling elevation and subsequently increased donation behavior. Future research may consider incorporating the aforementioned tactics in order to increase the mood state of elevation. In addition, further research with larger sample sizes is needed to elucidate the potential relationship between elevation and organ and tissue donation decision-making.

Based on prior research, it was predicted that women would score higher on elevation than men. Consistent with previous research, women scored higher on both state and trait elevation than men. However, outcomes for women were not significantly different than outcomes for men in this experiment. Furthermore, although women experience greater elevation than men, the mood state appears to have similar effects on decision making and behavior across gender.

The mental and physical health benefits of engaging in prosocial behavior have been well documented (Review by Post, 2005; Poulin, 2013). As such, it was predicted that trait elevation would be positively related to well-being. However, trait elevation did not predict well-being in this study.

Limitations. The sample in this study was homogenous in regards to race, gender, and age. The sample was predominantly White, female, and between the ages of 18 to 29. Previous research (Kuppens, Realo, \&Diener, 2008) has indicated that cultural differences may exist in the experience of positive emotions. Thus, a more heterogenous sample may yield discrepant results. Additionally, the Contemplation and Preparation stages had small sample sizes. Future studies may consider recruiting 
more participants in these stages specifically, because they would have indicated interest and may be easier to help increase their readiness to become an organ and tissue donor.

Future Directions. Suggestions for future research include that efforts should be made to include primarily participants in Pre-Action for becoming organ and tissue donors. The current study appears to have been statistically underpowered and as such analyses were unable to detect significant relationships between elevation and behavior change unless the baseline stage groups were combined (ultimately yielding more statistical power). Thus, this study should be replicated with a larger Pre-Action sample. In addition, given the homogeneity in our sample; replication with more variability among races may allow us to understand elevation within a cultural context. In addition, future studies should compare organ donation behavior change constructs to other types of prosocial behaviors. For example, future studies could include a simple donation task to better understand if elevation elicited though online dissemination can impact other prosocial behaviors that require less effort. Suggestions for future research using the TTM measures could be to consider not including these items in the decisional balance and self-efficacy measures due to their low endorsement.

In terms of practical considerations and intervention development, the DMV provides an opportune and convenient time to intervene. Future research could consider developing brief computer interventions to be disseminated at the DMV. In addition, web-based interventions can be developed when license-renewal is available online. Given the results of this study, further investigation is needed to understand if 
including a video clip of elevation within an online intervention could actually impact behavior change. However, this study provides solid empirical evidence that a video clip administered online was successful in eliciting the powerful, positive, pro-social emotion, elevation. 


\section{Appendix A: Informed Consent}

You have been invited to take part in this research project described below. If you have any questions, please feel free to call Nicole Amoyal, MS at 401-874-9040 or Mark Robbins, $\mathrm{PhD}$ at 401-874-5082 the people mainly responsible for this study. Description of the Project: The purpose of this experiment is to better understand more about attitudes towards organ donation. You will be asked to watch a video and answer questions about organ donation and related subject matter. You may stop the experiment at any time with no penalty. Responses to these items will be collected in an online survey and identifying information will not be asked.

2. What will be done: You are one of 700 College Students who will be asked to watch a video and complete a survey that asks about perceptions, attitudes and behaviors regarding organ donation and related subject matter. To participate, you must be at least 18 years of age, be able to read and speak English, and access this study on a computer with internet access and working speakers or headphones. This study is conducted entirely via the internet online and should take approximately 25 minutes, and you will receive research credit in exchange for your participation.

3. Study Risks or Discomforts: The possible risks or discomforts of this experiment are minimal.

4. Expected Study Benefits: You may not receive any direct benefit from taking part in this experiment. Taking part in the experiment, however, may help others like you in the future. Some people may find participation in this research informative and/or personally beneficial. Although there are no direct benefits of this study to you, your answers will help increase our scientific understanding of organ donation attitudes.

5. Participation in this experiment is completely confidential and anonymous. That means that your answers to all questions are private and your name will not be associated with any of the information you provide during the experiment. Scientific reports will be based on group data and will not identify you or any individual as participating in this project. Your responses to assessment questions will be stored in a secure database on a server of the company (Qualtrics) that is hosting the internet survey and on password protected computers at the Cancer Prevention Research Center. We will not collect or store IP addresses. After online data collection is complete, the data will be transferred to a secure server at URI which is firewall protected with restricted access to study personnel only.

6. Decision to Quit at Any Time: Taking part in this experiment is entirely voluntary and completely up to you. If you participate you must answer all questions. However, you may choose to not answer any of the questions with no penalty and this 
will allow you to discontinue the survey at any time. You need not give any reasons for discontinuation.

7. Participation in this study is not expected to be harmful or injurious to you. However, if this study causes you any injury, you should write or call Nicole Amoyal, MS or Mark Robbins, PhD, at the University of Rhode Island at (401) 874-9040. Additionally, if you are not satisfied with the way this study is performed, or if you have questions about your rights as a research subject, you may discuss your concerns with Dr. Mark Robbins (401-874-5082). In addition, you may contact the office of the Vice President of Research, 70 Lower College Road, Suite 2, University of Rhode Island, Kingston, RI 02882 (401-874-4328).

You are at least 18 years old. You have read this Consent Form and your questions have been answered to your satisfaction. You understand that you may ask any additional questions at any time and that your participation in this project is voluntary. Your filling out this survey implies your consent to participate in this experiment. If you want a copy of this form, please print it out.

Thank you in advance for your time,

Nicole Amoyal, M.S.

Clinical Psychology Doctoral Student

Mark Robbins, Ph.D.

Principal Investigator

I have read, understood, and printed a copy of, the above consent form and have desire of my own free will to participate in this study.

O Yes

$\mathrm{O}$ No 
Appendix B: Instructions Form

This online survey contains a video and questionnaires that are part of a dissertation project. Please fill out all of the information requested on your own. You may consult with the investigator if you have any questions via email at nnamoyal@gmail.com. It is important that you try to complete every item. Please make sure you are at a computer that will allow you to watch and listen to a short video. If you are not able to listen to and watch the video you will not get credit for your participation.

****IF YOU HAVE A MAC COMPUTER- THE VIDEOS WILL NOT WORK. PLEASE STOP THIS SURVEY AND TRY AGAIN FROM ANOTHER NON-MAC COMPUTER. WE APOLOGIZE FOR THE INCONVENIENCE****

Please read the instructions carefully and answer the questions as honestly and sincerely as possible. When you have completed all of the questionnaires please exit the website. Please do not print out the questionnaires. This will take you approximately 25 minutes to complete. Thank you.

O I have read the instructions. 
Appendix C: Demographics Form

What is your gender?

Female

Male

How old are you?

What year are you in school?

O Freshman

S Sophomore

O Junior

S Senior

Other

What is your ethnicity?

African American/ Black

O Asian/Pacific Islander

O White

O Hispanic

O Pacific Islander

Other

What is your religion?

O Catholic

O Protestant

O Jewish

Atheist

O Hindu

O Agnostic

Muslim

Other 
Appendix D: Organ Donation Stage of Change Questionnaire (Baseline)

Now I'm going to ask you some questions about organ and tissue donation. After people die, it is often possible to remove one or more of their organs and transplant them into another person whose own organs are failing. There are three steps to becoming an organ donor. The first step is making the decision to donate one's organs at the time of death. Have you made the decision to be an organ donor at the time of your death?

$\mathrm{O}$ Yes

$\mathrm{O}$ No

Have you made the decision to be an organ donor more or less than 6 months ago?

O Less than 6 months

More than 6 months

The second step to becoming an organ donor is informing your family, parents, or guardians of your decision to donate your organs at the time of your death. Have you told your family of your wish to donate your organs at the time of your death?

$\mathrm{O}$ Yes

$\mathrm{O}$ No

How long ago did you tell your family of your wish to donate your organs?

Less than 6 months

O More than 6 months

The third step is having a record of your decision to be an organ donor? (For example, a signed organ donor card or an organ donor sticker on your license.)

$\mathrm{O}$ Yes

No

Do you have a signed organ donor card?

$\mathrm{O}$ Yes

No

Do you have an organ donor sticker on your driver's license or state ID?

$\mathrm{O}$ Yes

O No

Are you a member of a state organ donor registry? A state organ donor registry is a list of people's names who have signed a card indicating that they are organ and tissue donors.

$\mathrm{O}$ Yes

O No 
How long have you had this record of your wishes to donate your organs?

O Less than 6 months

O More than 6 months

Are you planning on making the decision to become an organ donor within the next 6 months?

$\mathrm{O}$ Yes

O No

Are you planning on making the decision to become an organ donor within the next 30 days?

$O$ Yes

$\mathrm{O}$ No

Are you planning to tell your family of your decision to be an organ donor in the next 6 months?

$\mathrm{O}$ Yes

O No

Are you planning to tell your family of your decision to be an organ donor in the next 30 days?

$\mathrm{O}$ Yes

O No

Are you planning to get a record that you are an organ donor in the next 6 months?

$O$ Yes

O No

Are you planning to get a record that you are an organ donor in the next 30 days?

$O$ Yes

$\mathrm{O}$ No 
Appendix E: Organ Donation Decisional Balance Questionnaire (Baseline)

The following statements describe different opinions people may or may not have about organ donation. Please rate how important these statements are to you in deciding whether or not to be an organ donor. Please use the following 5-point scale. If you disagree with an item in this section of the survey that probably means it is not important in your decision and you can choose "not at all important."

$1=$ NOT AT ALL IMPORTANT

2 = SOMEWHAT IMPORTANT

$3=$ MODERATELY IMPORTANT

4 = VERY IMPORTANT

5 = EXTREMELY IMPORTANT

How important are the following opinions in your decision whether or not to be an organ donor?

\begin{tabular}{|l|l|l|l|l|l|}
\hline $\begin{array}{l}\text { Organ } \\
\text { donation } \\
\text { would allow } \\
\text { something } \\
\text { positive to } \\
\text { come out of } \\
\text { my death. }\end{array}$ & 0 & 0 & 0 & 0 & \\
$\begin{array}{l}\text { If I am an } \\
\text { organ donor, }\end{array}$ & & & & \\
$\begin{array}{l}\text { I might } \\
\text { prevent } \\
\text { another } \\
\text { family from } \\
\text { losing a } \\
\text { loved one. }\end{array}$ & 0 & 0 & 0 & 0 \\
\hline
\end{tabular}


Appendix F: Organ Donation Self-Efficacy Questionnaire (Baseline)

Think about the following situations that may affect your decision to become an organ donor. Please rate how confident you are to become an organ donor in the following situation using this 5-point scale:

$1=$ NOT AT ALL CONFIDENT

$2=$ NOT VERY CONFIDENT

$3=$ MODERATELY CONFIDENT

$4=$ VERY CONFIDENT

$5=$ EXTREMELY CONFIDENT

I AM CONFIDENT THAT I CAN BECOME AN ORGAN DONOR EVEN IF:

\begin{tabular}{|c|c|c|c|c|c|}
\hline $\begin{array}{l}\text { My family } \\
\text { is against } \\
\text { organ } \\
\text { donation. }\end{array}$ & 0 & 0 & 0 & O & O \\
\hline $\begin{array}{l}\text { I don't have } \\
\text { much time } \\
\text { to make the } \\
\text { decision. }\end{array}$ & 0 & 0 & 0 & 0 & 0 \\
\hline
\end{tabular}




\title{
Appendix G: Elevation Trait Questionnaire
}

We sometimes read or hear or see stories about people who went out of their way to help others, or who did something kind or compassionate or courageous or beautiful. How many times per month would you say you come across such stories, on average?

\author{
O Never \\ O Once or twice \\ O 3 to 5 times (about once per week) \\ O 6-14 times \\ O 15-30 times (on most days) \\ 31+ times (at least once a day, on average)
}


When you do come across such stories, do they have any of the following effects on you?

\begin{tabular}{|c|c|c|c|c|}
\hline $\begin{array}{l}\text { I get "choked } \\
\text { up" (a feeling in } \\
\text { my throat) }\end{array}$ & O & $\mathrm{O}$ & $\mathrm{O}$ & O \\
\hline $\begin{array}{l}\text { I feel tingles or } \\
\text { chills or goose } \\
\text { bumps }\end{array}$ & 0 & O & $\mathrm{O}$ & O \\
\hline $\begin{array}{l}\text { I feel a cool, } \\
\text { pleasant feeling } \\
\text { in my stomach }\end{array}$ & O & 0 & O & 0 \\
\hline $\begin{array}{l}\text { I feel like I } \\
\text { want to do } \\
\text { something good } \\
\text { too }\end{array}$ & O & 0 & O & $\mathrm{O}$ \\
\hline $\begin{array}{l}\text { I get tears in my } \\
\text { eyes }\end{array}$ & 0 & 0 & O & O \\
\hline $\begin{array}{l}\text { It makes me } \\
\text { feel that I am } \\
\text { somehow a } \\
\text { worse person, } \\
\text { in contrast to } \\
\text { that person }\end{array}$ & O & $\mathrm{O}$ & $\mathrm{O}$ & O \\
\hline I feel happy & $\mathrm{O}$ & $\mathrm{O}$ & $\mathrm{O}$ & O \\
\hline $\begin{array}{l}\text { I feel a warm or } \\
\text { glowing feeling } \\
\text { in my chest }\end{array}$ & 0 & O & O & O \\
\hline $\begin{array}{l}\text { I have a hot, } \\
\text { flushed feeling } \\
\text { in my face }\end{array}$ & 0 & O & O & O \\
\hline $\begin{array}{l}\text { It makes me } \\
\text { feel that I am } \\
\text { somehow } \\
\text { "lifted up" or } \\
\text { "nobler" myself }\end{array}$ & 0 & O & 0 & 0 \\
\hline $\begin{array}{l}\text { It makes me } \\
\text { want to tell the } \\
\text { story to other } \\
\text { people }\end{array}$ & O & $\mathrm{O}$ & $\mathrm{O}$ & O \\
\hline $\begin{array}{l}\text { It makes me } \\
\text { want to thank or } \\
\text { reward the }\end{array}$ & 0 & 0 & O & 0 \\
\hline
\end{tabular}




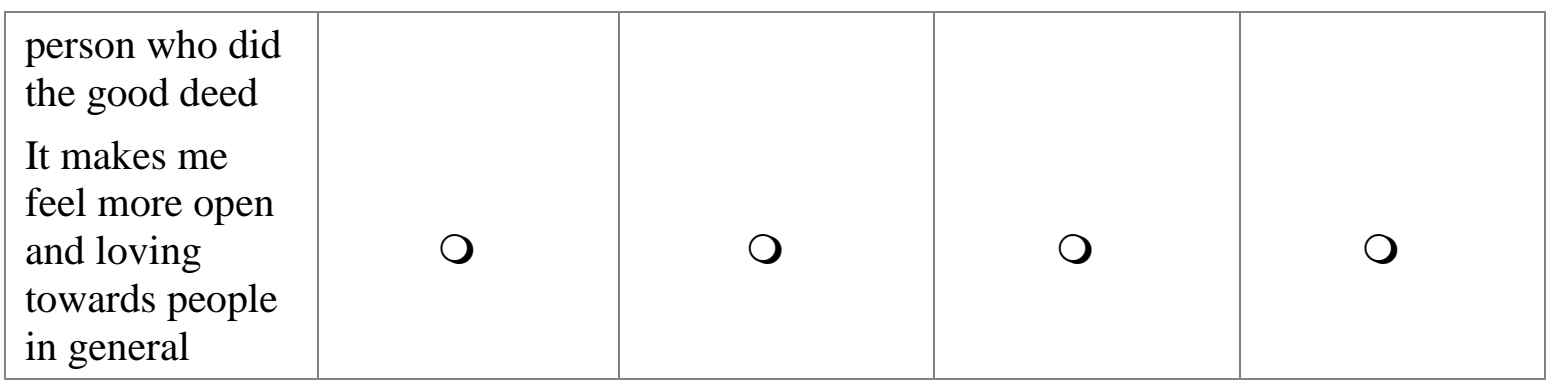




\section{Appendix H: Video Manipulation Check}

What was Fernando given as a surprise in the video clip?

O A surprise birthday party

O A new car

O Free tickets to the Oprah Winfrey Show

O His students wanted to thank him

In the video, who does Dmitri Martin think should throw stones?

O Elves

O Rabbits

O People trapped in glass houses

O College Students

In the video, Beluga Whales are sometimes called:

O Sea Canaries

O Sea Marshmallows

O Sea Monkeys

Sea Dragons 


\section{Appendix I: Elevation State Questionnaire}

Please describe how you felt immediately after watching the film by circling the number which best reflects how strongly you felt each of these emotions from 1 (didn't feel at all) to 9 (felt very strongly).

\begin{tabular}{|c|c|c|c|c|c|c|c|c|c|}
\hline Moved & $\mathrm{O}$ & 0 & $\mathrm{O}$ & $\mathrm{O}$ & 0 & 0 & 0 & 0 & 0 \\
\hline Uplifted & 0 & 0 & $\mathrm{O}$ & 0 & 0 & 0 & $\mathrm{O}$ & O & O \\
\hline Amused & $\mathrm{O}$ & $\mathrm{O}$ & 0 & $\mathrm{O}$ & 0 & 0 & 0 & 0 & 0 \\
\hline $\begin{array}{l}\text { Optimistic } \\
\text { about } \\
\text { humanity }\end{array}$ & 0 & O & 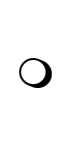 & $\mathrm{O}$ & 0 & 0 & $\mathrm{O}$ & O & O \\
\hline Happy & O & 0 & $\mathrm{O}$ & $\bigcirc$ & $\mathrm{O}$ & 0 & O & O & O \\
\hline $\begin{array}{l}\text { 'Warm' } \\
\text { Feeling in } \\
\text { chest }\end{array}$ & $\mathrm{O}$ & O & $\mathrm{O}$ & $\mathrm{O}$ & $\mathrm{O}$ & 0 & $\mathrm{O}$ & 0 & O \\
\hline $\begin{array}{l}\text { Want to } \\
\text { help } \\
\text { others }\end{array}$ & 0 & 0 & 0 & $\mathrm{O}$ & 0 & 0 & $\mathrm{O}$ & 0 & O \\
\hline $\begin{array}{l}\text { Want to } \\
\text { become a } \\
\text { better } \\
\text { person }\end{array}$ & $\mathrm{O}$ & 0 & $\mathrm{O}$ & 0 & $\mathrm{O}$ & $\mathrm{O}$ & $\mathrm{O}$ & O & O \\
\hline
\end{tabular}


Appendix J: Organ Donation Staging Questionnaire (Post-test)

Are you planning on making the decision to become an organ donor within the next 6 months?

$O$ Yes

O No

Are you planning on making the decision to become an organ donor within the next 30 days?

$\mathrm{O}$ Yes

O No

Are you planning to tell your family of your decision to be an organ donor in the next 6 months?

$O$ Yes

No

Are you planning to tell your family of your decision to be an organ donor in the next 30 days?

$\mathrm{O}$ Yes

O No

Are you planning to get a record that you are an organ donor in the next 6 months?

$O$ Yes

O No

Are you planning to get a record that you are an organ donor in the next 30 days?

$O$ Yes

O No 
Appendix K: Organ Donation Decisional Balance Questionnaire (Post-Test)

The following statements describe different opinions people may or may not have about organ donation. Please rate how important these statements are to you in deciding whether or not to be an organ donor. Please use the following 5-point scale. If you disagree with an item in this section of the survey that probably means it is not important in your decision.

$$
\begin{aligned}
& 1=\text { NOT AT ALL IMPORTANT } \\
& 2=\text { SOMEWHAT IMPORTANT } \\
& 3=\text { MODERATELY IMPORTANT } \\
& 4=\text { VERY IMPORTANT } \\
& 5=\text { EXTREMELY IMPORTANT }
\end{aligned}
$$

How important are the following opinions in your decision whether or not to be an organ donor? 


\begin{tabular}{|c|c|c|c|c|c|}
\hline $\begin{array}{l}\text { If I become an } \\
\text { organ donor, I } \\
\text { will not be } \\
\text { 'whole' in my } \\
\text { life after } \\
\text { death? }\end{array}$ & 0 & 0 & 0 & 0 & 0 \\
\hline $\begin{array}{l}\text { Organ } \\
\text { donation } \\
\text { would allow } \\
\text { something } \\
\text { positive to } \\
\text { come out of } \\
\text { my death. }\end{array}$ & 0 & 0 & 0 & 0 & 0 \\
\hline $\begin{array}{l}\text { Becoming an } \\
\text { organ donor } \\
\text { would upset } \\
\text { my family. }\end{array}$ & 0 & 0 & 0 & 0 & 0 \\
\hline $\begin{array}{l}\text { If I become an } \\
\text { organ donor I } \\
\text { won't have } \\
\text { control over } \\
\text { who receives } \\
\text { my organs. }\end{array}$ & 0 & 0 & 0 & 0 & 0 \\
\hline $\begin{array}{l}\text { Becoming an } \\
\text { organ donor is } \\
\text { one way of } \\
\text { doing God's } \\
\text { work. }\end{array}$ & 0 & 0 & 0 & 0 & 0 \\
\hline $\begin{array}{l}\text { My family } \\
\text { would worry } \\
\text { about me if I } \\
\text { am an organ } \\
\text { donor. }\end{array}$ & 0 & 0 & 0 & 0 & 0 \\
\hline $\begin{array}{l}\text { Becoming an } \\
\text { organ donor is } \\
\text { the right thing } \\
\text { to do. }\end{array}$ & 0 & 0 & 0 & 0 & 0 \\
\hline $\begin{array}{l}\text { My family } \\
\text { disapproves of } \\
\text { organ } \\
\text { donation. }\end{array}$ & 0 & 0 & 0 & 0 & 0 \\
\hline
\end{tabular}




\begin{tabular}{|c|c|c|c|c|c|}
\hline $\begin{array}{l}\text { It would help } \\
\text { my family to } \\
\text { know my } \\
\text { wishes to } \\
\text { become an } \\
\text { organ donor in } \\
\text { the event of } \\
\text { my death. }\end{array}$ & 0 & 0 & 0 & 0 & 0 \\
\hline $\begin{array}{l}\text { There is a } \\
\text { special need } \\
\text { for organ } \\
\text { donation in my } \\
\text { race. }\end{array}$ & 0 & 0 & 0 & 0 & 0 \\
\hline $\begin{array}{l}\text { Thinking } \\
\text { about donating } \\
\text { my organs } \\
\text { after I die } \\
\text { makes me } \\
\text { uncomfortable. }\end{array}$ & 0 & 0 & 0 & 0 & 0 \\
\hline $\begin{array}{l}\text { Organ } \\
\text { donation is } \\
\text { against my } \\
\text { religious } \\
\text { beliefs. }\end{array}$ & 0 & 0 & 0 & 0 & 0 \\
\hline $\begin{array}{l}\text { If I am an } \\
\text { organ donor, I } \\
\text { might prevent } \\
\text { another family } \\
\text { from losing a } \\
\text { loved one. }\end{array}$ & 0 & 0 & 0 & 0 & 0 \\
\hline $\begin{array}{l}\text { I would show } \\
\text { that I am } \\
\text { responsible by } \\
\text { becoming an } \\
\text { organ donor. }\end{array}$ & 0 & 0 & 0 & 0 & 0 \\
\hline
\end{tabular}




\section{Appendix L: Organ Donation Self-Efficacy}

Think about the following situations that may affect your decision to become an organ donor. Please rate how confident you are to become an organ donor in the following situation using this 5-point scale:

$1=$ NOT AT ALL CONFIDENT

$2=$ NOT VERY CONFIDENT

$3=$ MODERATELY CONFIDENT

$4=$ VERY CONFIDENT

$5=$ EXTREMELY CONFIDENT

I AM CONFIDENT THAT I CAN BECOME AN ORGAN DONOR EVEN IF:

\begin{tabular}{|c|c|c|c|c|c|}
\hline $\begin{array}{l}\text { My family } \\
\text { is against } \\
\text { organ } \\
\text { donation. }\end{array}$ & $\bigcirc$ & 0 & 0 & 0 & 0 \\
\hline $\begin{array}{l}\text { I don't have } \\
\text { much time } \\
\text { to make the } \\
\text { decision. }\end{array}$ & 0 & 0 & 0 & 0 & 0 \\
\hline $\begin{array}{l}\text { I am asked } \\
\text { to become a } \\
\text { donor by } \\
\text { someone I } \\
\text { don't know. }\end{array}$ & $\bigcirc$ & 0 & 0 & 0 & 0 \\
\hline $\begin{array}{l}\text { My friends } \\
\text { are against } \\
\text { organ } \\
\text { donation. }\end{array}$ & 0 & 0 & 0 & 0 & 0 \\
\hline $\begin{array}{l}\text { I feel } \\
\text { pressured by } \\
\text { others to } \\
\text { become an } \\
\text { organ donor. }\end{array}$ & 0 & 0 & 0 & 0 & 0 \\
\hline $\begin{array}{l}\text { I hear about } \\
\text { situations } \\
\text { where organ } \\
\text { donation } \\
\text { didn't work. }\end{array}$ & 0 & 0 & 0 & 0 & 0 \\
\hline
\end{tabular}




\section{Appendix M: Organ Donation Engagement Questionnaire}

How personally relevant is the subject matter of organ donation to you?

Drag slider

How interested are you in learning more about organ donation?

Drag slider

How likely are you to register as an organ donor at the next possible opportunity?

Drag slider

How likely are you to speak with your family about organ donation at the next possible opportunity?

Drag slider

How likely are you to register with organ donation registry (either at the DMV or online) at the next possible opportunity?

Drag slider

Would you like to register as an organ donor now?

$\mathrm{O}$ Yes

$\mathrm{O}$ No 


\section{Appendix N: Well-Being and Stress Management}

These next questions are about stress management and life satisfaction. Please imagine a ladder with steps numbered from zero at the bottom to ten at the top. The top of the ladder (10) represents the best possible life for you and the bottom of the ladder (0) represents the worst possible life for you. On which step of the ladder would you say you personally feel you stand at this time? (move slider over to a value from 0 worst possible life - 10 best possible life)

On which step of the ladder would you say you personally feel you stand at this time?

Just your best guess, on which step do you think you will stand in the future, say about five years from now?

Please answer the following questions and use a (1-10 Scale for both items 1- I'm at my worst 5- I'm soso 10- I'm at my best)

How are you feeling today?

How are you functioning today? 
Please answer the following questions as best as it pertains to you.

I feel that there is no one I can share my most private worries and fears with.

If I were sick, I could easily find someone to help me with my daily chores.

When I need suggestions on how to deal with a personal problem, I know someone I can turn to.

I don't often get invited to do things with others.

If I wanted to have lunch with someone, I could easily find someone to join me.

If I needed some help in moving to a new house or apartment, I would have a hard time finding someone to. 
Stress management includes regular relaxation, physical activity, talking with others, and/or making time for social activities. Do you effectively practice stress management in your daily life?

O No, and I do not intend to in the next 6 months

No, but I intend to in the next 6 months

No, but I intend to in the next 30 days

Yes, I have been but for less than 6 months

Yes, I have been for more than 6 months

I currently do not have any stress in my life 
Appendix O: Organ Donation Registration

You stated that you would like to register as an organ donor now. Please click yes AND then click on the link below if you would like this survey to connect you to the national organ donation registry. Registration takes less than 5 minutes. Please click no if you would not like to continue on to your state's registry.

Y Yes: http://organdonor.gov/becomingdonor/index.html

No 


\section{Appendix P: Organ Donation Incentive Instructions}

Thank you for your participation in this dissertation research study! You have completed this experiment. In order to compensate you for your time, please print this page for your records and turn it into your professor for research credit. If you have any questions please email the investigator Nicole Amoyal at nnamoyal@gmail.com with your name and contact information. 


\section{References}

National Kidney Donation Factsheet.(n.d.)Retrieved July 1, 2011, from www.kidney.org. Bandura A (1977) Self-efficacy: Toward a unifying theory of behavioral change. Psychological review, 84(2), 191-215.

Burditt, C., Paiva, A., Robbins, M., Velicer, W., Koblin, B., \& Kessler, D. (2009). Motivation for blood donation among African Americans: Developing measures for stage of change, decisional balance, and self-efficacy constructs. Journal of Behavioral Medicine, 32(5), 429-442.

Cantril H. The pattern of human concerns. New Brunswick, NJ: Rutgers University Press, 1965.

Cavanaugh, L. (2009). Feeling Good and Doing Better: How Specific Positive Emotions Influence Consumer Behavior and Well-being. (Unpublished doctoral dissertation). Duke University, North Carolina.

Chickering, A. W. and Kytle, J. (1999).The collegiate ideal in the twenty-first century.ln J. D.

Toma and A.J. Kezar (Eds.), Reconceptualizing the collegiate ideal (New directions for higher education, No. 105) (pp. 109-120) San Francisco: Jossey-Bass.

Cox, K. K. S. (2010). Elevation predicts domain-specific volunteerism 3 months later. The Journal of Positive Psychology, 5(5), 333-341.

Diener, E., Oishi, S., \& Lucas, R. (2003). Personality, Culture, and Subjective WellBeing: Emotional and Cognitive Evaluations of Life. Annual Review of Psychology, (54), 403- 425. DOI: 10.1146/annurev.psych.54.101601.145056 
DiClemente, C., Prochaska, J. (1985) Processes and stages of self-change: Coping and competence in smoking behavior change. In: S Shiffman, TA Wills, eds. Coping and Substance Use. New York: Academic Press, 319-343.

DiClemente, C., Prochaska, J. (1982) Self-change and therapy change of smoking behavior: a comparison of processes of change in cessation and maintenance. Addictive Behaviors, 7(2), 133-42.

DiClemente C., Prochaska, J., Gibertini, M. (1985) Self-efficacy and the stages of selfchange of smoking. Cognitive Therapy and Research, 9(2), 181-200.

DiClemente, C., Prochaska, J., Fairhurst, S., Velicer, W., Velasquez, M., Rossi, J. (1991) The process of smoking cessation: An analysis of precontemplation, contemplation, and preparation stages of change. Journal of consulting and clinical psychology, 59(2), 295-304.

Dvorkin, J. A. (2006, March 7). Is compassion fatigue setting in? Retrieved April 21, 2006, from http://www.npr.org/templates/story/story.php?storyId=5249873

Fava, Joseph L., Laurie Ruggiero and Diane M. Grimley (2008).The Development and Structural Confirmation of the Rhode Island Stress and Coping Inventory.Journal of Behavioral Medicine. 21(6):601-611.

Fredrickson, B. L. (2001). The role of positive emotions in positive psychology: The broaden-and-build theory of positive emotions.American Psychologist, 56, 218226. MACROBUTTON HtmlResAnchor doi:10.1037/0003-066X.56.3.218

Fredrickson, B. L. (2006). The broaden-and-build theory of positive emotions. In M. Csikszentmihalyi\& I. S. Csikszentmihalyi (Eds.), A life worth living: 
Contributions to positive psychology (pp. 85-103). New York, NY. Oxford University Press. doi:10.1037/0003-066X.56.3.218

Freeman D., Aquino, K., \&McFerran, B. (2009). Overcoming beneficiary race as an impediment to charitable donation: Social dominance orientation, the experience of moral elevation, and donation behavior.Personality and Social Psychology Bulletin, 35, 72-84. doi:10.1177/0146167208325415

Garland, E., Fredrickson, B, Kring, A., Johnson, D., Meyer, P., \& Penn, D (2010). Upward spirals of positive emotions counter downward spirals of negativity: Insights from the broaden-and-build theory and affective neuroscience on the treatment of emotion dysfunctions and deficits in psychopathology.Clinical Psychology Review, 30(7), 849.

Gore, S., \&Aseltine, R. (2003). Race and Ethnic Differences in Depressed Mood Following the Transition from High School.Journal of Health and Social Behavior, 44(3), 370-389.

Haidt, J. (2000). The positive emotion of elevation.Prevention and Treatment, 3, 15.doi:10.1037/1522-3736.3.1.33c

Haidt, J. (2003). Elevation and the positive psychology of morality.In C. L. M. Keyes \& J. Haidt (Eds.), Flourishing: Positive psychology and the life well-lived (pp. 275289). Washington, DC: American Psychological Association. doi:10.1037/10594Haidt, J., \&Keltner, D. (2004).Appreciation of beauty and excellence.In C. Peterson \& M. E. P. Seligman (Eds.), Character strengths and virtues (pp. 537-551). Washington, DC: American Psychological Association. 
Hall, K. L., Robbins, M. L., Paiva, A., Knott, J. E., Harris, L., \&Mattice, B. (2007). Donation intentions among africanamerican college students: Decisional balance and self-efficacy measures. Journal of Behavioral Medicine, 30(6), 483-495. doi:10.1007/s10865-007-9121-8.

Hall KL, Rossi JS (2008) Meta-analytic examination of the strong and weak principles across 48 health behaviors. Preventive Medicine: An International Journal Devoted to Practice and Theory, 46(3), 266-74.

Kavanagh, D. D. J. (1985). Mood and self-efficacy: Impact of joy and sadness on perceived capabilities. Cognitive Therapy and Research, 9(5), 507-525.

Landis, S. K., Sherman, M. F., Piedmont, R. L., Kirkhart, M. W., Rapp, E. M., \& Bike,

D. H. (2009). The relation between elevation and self-reported prosocial behavior: Incremental validity over the five-factor model of personality. Journal of Positive Psychology, 4, 71-84. doi:10.1080/17439760802399208

Milaniak, I., Przybylowski, P., Wierzbicki, K., \&Sadowski, J. (2010). Organ transplant education: The way to form altruistic behaviors among secondary school students toward organ donation. Transplantation Proceedings, 42(1), 130-133. doi:DOI: 10.1016/j.transproceed.2009.12.040

Post, S. S. G. (2005). Altruism, happiness, and health: It's good to be good. International Journal of Behavioral Medicine, 12(2), 66-77.

Prochaska JO, Velicer WF, DiClemente CC, Fava J (1988) Measuring processes of change: applications to the cessation of smoking. Journal of consulting and clinical psychology, 56(4), 520-8. 
Prochaska JO, Norcross JC (1983) Psychotherapists' perspectives on treating themselves and their clients for psychic distress. Professional Psychology: Research and Practice, 14(5), 642-55.

Prochaska JO, DiClemente CC (1983) Stages and processes of self-change of smoking: Toward an integrative model of change. Journal of consulting and clinical psychology, 51(3), 390-5.

Prochaska JO, Velicer WF, Rossi JS, Goldstein MG, Marcus BH, Rakowski W, Fiore C, Harlow LL, Redding CA, Rosenbloom D, Rossi SR (1994) Stages of change and decisional balance for 12 problem behaviors. Health Psychology, 13(1), 39-46.

Prochaska, James O.; DiClemente, Carlo C.; Norcross, John C. (1992) In search of how people change: Applications to addictive behaviors. American Psychologist, $\mathrm{Vol}$ 47(9), Sep 1992, 1102-1114. doi: 10.1037/0003-066X.47.9.1102

Prochaska JO, DiClemente CC (1985) Common Processes of Change in Smoking, Weight Control and Psychological Distress In: S Shiffman, TA Wills, eds.Coping and Substance Abuse. New York: Academic Press, 345-362.

Robbins ML, Levesque DA, Redding CA, Johnson JL, Prochaska JO, Rohr MS, Peters TG (2001) Assessing family members' motivational readiness and decision making for consenting to cadaveric organ donation. Journal of Health Psychology, 6, 523-35.

Robbins, M. L. (1998). Applying a readiness model to increasing organ donation and Transplantation. Medicine and Health, Rhode Island, 81, 294-296.

Schnall, S., Roper, J., \&Fessler, D. (2010). Elevation leads to altruistic behavior. Psychological Science, 21, 1-6. doi:10.1177/0956797609359882 
Siegel, J. T., Alvaro, E. M., Crano, W. D., Lac, A., Ting, S., \& Jones, S. P. (2008).A quasi-experimental investigation of message appeal variations on organ donor registration rates. Health Psychology, 27(2), 170-178. doi:DOI: 10.1037/02786133.27 .2 .170

Silvers, J. A., \&Haidt, J. (2008). Moral elevation can induce nursing. Emotion, 8, 291295. doi:10.1037/1528-3542.8.2.291

Tugade, M. M., Fredrickson, B. L., \& Barrett, L. F. (2004). Psychological resilience and positive emotional granularity: Examining the benefits of positive emotions on coping and health. Journal of Personality, 72, 1161-1190. doi:10.1111/j.1467$\underline{6494.2004 .00294 . x}$

Velicer WF, Prochaska JO, Bellis JM, DiClemente CC, Rossi JS, Fava JL, Steiger JH (1993) An expert system intervention for smoking cessation. Addictive Behaviors, 18(3), 269-90.

Velicer WF, DiClemente CC, Prochaska JO, Brandenburg N (1985) Decisional balance measure for assessing and predicting smoking status. Journal of personality and social psychology, 48(5), 1279-89.

Vianello, M. M. (2010). Elevation at work: The effects of leaders' moral excellence. The Journal of Positive Psychology, 5(5), 390-411.

Waterman, A, Robbins, M, Paiva, A., \& Hyland, S. (2010). Kidney patients' intention to receive a deceased donor transplant: Development of stage of change, decisional balance and self-efficacy measures. Journal of Health Psychology, 15(3), 436445. 